\title{
Battery Management System in Electric Vehicles
}

\author{
Prof Rakshitha R, Assistant Professor RVITM; PhD Scholar, Christ University \\ Dr Usha Surendra, Professor ,EEE Department Christ University
}

\section{Abstract}

Here this document provides the data about the batteries of electric vehicles. It consists of numerous data about various energy storage methods in EVs and how it is different from energy storage of IC-engine vehicles. How electric vehicles will take over ICEngine vehicles due to advancement in battery technology and the shrink in its prices. Various types of batteries are listed in the document with their specifications. Possible future battery technology which will have more or same energy density than current gasoline fuels and also with the significant reduction in battery weights; which will make EVs cheaper than current condition. Some examples are listed showing current battery capacities of various EVs models. Some battery parameters are shown in the document with introduction to BMS (Battery Management System). Then a brief introduction about the charging of these EV batteries and its types displaying variations in charging time in different types of EVs according to their charger type and manufacturers. How DC charging is more time saving method than AC and how smart charging will help to grid in case of peak or grid failure conditions.

Keywords- EV Batteries, EV Energy Storage, EV Charging, AC Charging, DC Charging, Smart Charging, V2X, Batteries, Electric Vehicles

\section{INTRODUCTION}

Batteries of an electric-vehicles are those which used to power the propulsion of battery electric vehicles (BEVs). They are also known as traction batteries. In routine vehicles, rechargeable batteries are used for the secondary purpose. The main source of energy to power the propulsion in this vehicle is usually IC engines which have around 38\% efficiency and produces exhaust gases which are noxious for the environment, where in case of electric-vehicles traction batteries are used to power the main motor of the electricvehicle having $90-95 \%$ efficiency. Traction batteries are primarily used in electric-vehicles, golf carts, electric motorcycles, forklifts and other vehicles. Electric-vehicle batteries are the conflict with SLI (starting, lighting, and ignition) batteries due to nature of providing power for the sustained period of time. For this application, Deep-cycle batteries are used contrary to SLI batteries. Traction batteries must be drafted with the high ampere-hour capacity. Electric-vehicles batteries are classified on the basis of their relatively high power-weight ratio, energy-weight ratio, and energy density. For improved performance and reduce the weight of the vehicle; smaller and lighter batteries are used. Rechargeable batteries used in electric vehicles are comprise lead-acid, nickel-metal hydride, $\mathrm{NiCd}$, lithium-ion, lithium polymer and less frequently zinc-air and moltensalt batteries. Electricity stored in batteries are measured in ampere hours and total energy measured in watt hours. For EVs, batteries make up significant cost unlike fossil-fuelled cars. The batteries can be discharged and recharged each day... Perhaps most notable, battery costs have plummeted [1]; and from 2008 to 2014, the cost of electric vehicle batteries has been reduced by more than 35\% [2]. In 2020, the predicted market for automobile traction batteries is over $\$ 37$ billion [3]. The operating cost of electric vehicle is a small fraction of the operating cost for IC engines, which reflects higher energy efficiency. The cost of replacing the batteries dominates the operating costs [4].

\section{A. Energy Storage: Gasoline Vs Batteries}

The main reason why the electric car didn't make it before was because of the size and weight of the battery that was needed. Back then fuel proved to be a far more efficient way of energy storage. But as you can see in the table below, battery technologies have developed to the point where size and weight are much less of an issue.

Table 1: Improvement in battery technologies over the years (for

\begin{tabular}{|c|c|c|c|}
\hline $\begin{array}{l}\text { Energy } \\
\text { Source }\end{array}$ & Year & $\begin{array}{l}\text { Energy } \\
(\mathrm{Whr} / \mathrm{kg})\end{array}$ & $\begin{array}{l}\text { Compared to } \\
\text { gasoline }\end{array}$ \\
\hline Gasoline & $\begin{array}{l}1900- \\
20 ? ?\end{array}$ & 12,000 & - \\
\hline Lead-acid & 1900 & 10 & 1,2000 X worse \\
\hline Lead-acid & 2000 & 35 & 350 X worse \\
\hline NiMH & 2000 & 80 & 150 X worse \\
\hline Lithium & 2015 & 250 & 50 X worse \\
\hline Lithium & 2015 & 400 & 30 X worse \\
\hline Lithium-air & $? ? ?$ & 12,000 & Same \\
\hline \multicolumn{4}{|c|}{ energy) }
\end{tabular}

If you simplify this table, you can easily compare how much weight you need to bring in your car to get $500 \mathrm{~km}$ extra range with each type of battery. 
Table 2: Improvement in battery technologies over the years (for weight)

\begin{tabular}{|c|c|c|c|}
\hline $\begin{array}{l}\text { Energy } \\
\text { Source }\end{array}$ & Year & $\begin{array}{l}\text { Extra weight needed for 500 } \\
\mathrm{km}(\mathrm{kg})\end{array}$ & Equals \\
\hline Lead-acid & 1900 & 10,000 & Elephant \\
\hline Lead-acid & 2000 & 3,000 & Rhinoceros \\
\hline NiMH & 2000 & 800 & Bison \\
\hline Lithium & 2015 & 400 & Gorilla \\
\hline Lithium & $2025 ?$ & 200 & Pig \\
\hline
\end{tabular}

As shown in table and these developments, the electric car will soon be lighter than the ICE cars, if you take the weight of the drivetrain and the energy storage together into account. Further, as you can see from this, battery prices are also swiftly plummeting, meaning that the electric car will soon also be cheaper [5].

\section{ENERGY STORAGE IN EVS}

Electromechanical storage devices used in EVs must fulfil certain requirements, so that the $\mathrm{EV}$ can perform in a satisfactory manner. The key requirements are as follows:

- Charge and discharge cycles should have high efficiency

- Under wide range of conditions operation should be safe

- Specific power should be high to meet driver's acceleration expectations

- High specific energy to ensure the satisfactory range

- Maintenance free and long lifetime

- Minimum effect on environment due to end of life disposal

The power and energy requirements for different types of EVs in comparison with HEV (Hybrid Electric Vehicle) and PHEV (Plug in Hybrid Electric Vehicle) are listed below, together with common voltage ratings. For the purpose of this module five categories of EV batteries are described, which is similar to that described by Van den Bossche [6] and Westbrook [7]. - Lead acid

- Nickel based: NiMH, NiCad

- High temperature: Sodium-nickel-chloride ( $\mathrm{NaNiCl}$ or Zebra)

- Lithium based: Lithium-ion (Li-ion) and Lithiumpolymer (Li-poly)

- Metal air: Aluminium air (Al-air) and Zinc-air (ZN-air) Table 3: Typical EV Battery Electrical Parameters

\begin{tabular}{|c|c|c|c|}
\hline EV type & Power $(k W)$ & Energy $(k W h)$ & Voltage $(V)$ \\
\hline HEV & $20-50$ & $1-3$ & $200-350$ \\
\hline PHEV & $>40$ & $2-15$ & $200-500$ \\
\hline$B E V$ & $>80$ & $25-100$ & $200-1000$ \\
\hline
\end{tabular}

\section{A. Types of Batteries}

\section{1) Lead Acid Batteries}

This is a mature technology where limited progress has been made in terms of energy and power density. Deep cycle batteries are available, which have re-enforced electrode to avoid separation and sludge formation [8]. Prospects for use in EVs are limited, due to low energy densities, sensitivity to temperature and life cycle [9].

\section{2) Nickel Based Batteries}

Nickel-metal hydride (NiMH) batteries are used extensively for traction purpose, and are optimized for high energy current. Nickelcadmium (NiCD) batteries also show good potential for high specific energy and specific power, although the presence of cadmium has raised some environmental concerns [10].

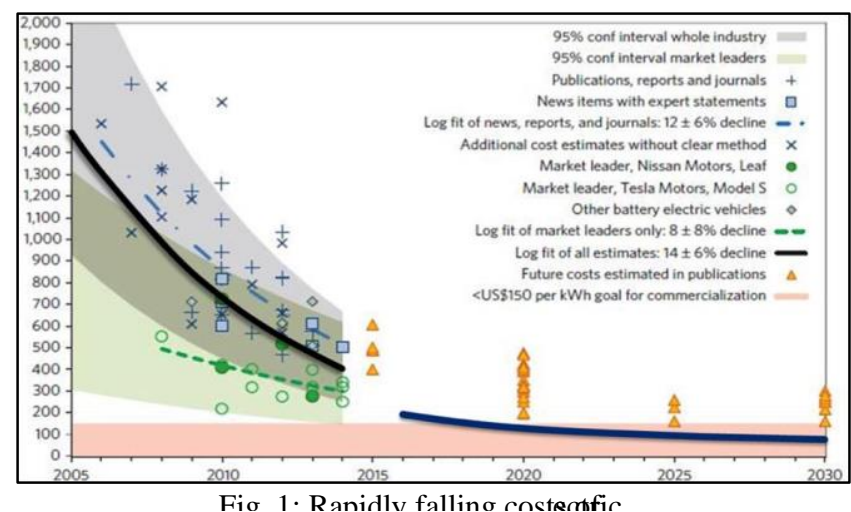

3) High Temperature Batteries

Sodium-nickel chloride $(\mathrm{NaNiCl}$ or Zebra) batteries have been deployed in numerous EV applications to date [11]. The high specific energy is attractive for long range EVs. The high operating temperature $\left(300^{\circ} \mathrm{C}\right)$ requires pre-heating before use, which can use quite a lot of energy if parked regularly for long periods. For this reason, this battery is considered more suitable to applications where the EV is being used continuously (public transport and delivery vans etc.).

\section{4) Metal Air Batteries}

Aluminium-air (Al-air) and zinc-air (Zn-air) batteries both use oxygen absorbed from the atmosphere on discharge and expel oxygen when being charged. The energy density of these batteries is high but, lower power densities mean that applications are limited. Al-air batteries consume the aluminium electrode, and must be removed and replaced or reprocessed. Some applications have been tested where fleets of EV delivery vehicles are running with $\mathrm{Zn}$-air batteries, where removable zinc cassettes can be replaced when discharged for recharged units. The low specific power of metal air batteries may see these battery types restricted to long distance delivery vehicles, but the advantages of regenerative braking may be sacrificed.

\section{5) Lithium Based Batteries}

Lithium based batteries are classified by the type of active material. Two main types exist, those with liquid (Li-ionliquid) and those with polymer electrolyte (Li-ion-polymer). The Li-ion-liquid type is generally preferred for $\mathrm{EV}$ applications. Within the Liion-liquid type, there are three lithium materials, lithium cobalt, (or lithium manganese oxides), lithium iron phosphate and lithium titanate.

a) Lithium Manganese

Lithium manganese (LiMn2O4) offers a potentially lower cost solution. It has been largely studied for electrical vehicle application, especially in Japan. The drawback of this type of battery is the poor battery life due to the slight solubility of Mn. b) Lithium Iron Phosphate 
Lithium iron phosphate (LiFePO4) batteries are manufactured by many companies in the world and have gained credibility through their use in power tools. Lithium iron phosphate cells have a much lower energy density than standard format cells, but can be charged much fasteraround twenty to thirty minutes. Moreover, LiFePO4 has been recently considered that it features an improve stability on overcharge which is good for safety, a very high power and has potential for lower cost because they use iron. c) Lithium Titanate

Lithium titanate allows charging on the order of ten minutes and have been shown to have an extremely long cycle life on the order of 5000 full depth of discharge cycles. Lithium titanate has high inherent safety because the graphite anode of two other batteries is replaced with a titanium oxide.

Table 4: Qualitative Comparison of EV Batteries [12]

\begin{tabular}{|c|c|c|c|c|c|}
\hline Attribute & $\begin{array}{l}\text { Lead- } \\
\text { acid }\end{array}$ & $\begin{array}{l}\mathrm{Ni}- \\
\mathrm{MH}\end{array}$ & ZEBRA & $\begin{array}{l}\text { Metal- } \\
\text { air }\end{array}$ & $\begin{array}{l}\mathrm{Li}- \\
\text { ion }\end{array}$ \\
\hline $\begin{array}{c}\text { Specific energy } \\
(k W k g-1)\end{array}$ & 1 & 2 & 3 & 3 & 3 \\
\hline $\begin{array}{c}\text { Specific Power } \\
(k W k g-1)\end{array}$ & 1 & 3 & 1 & 1 & 3 \\
\hline $\begin{array}{c}\text { Capacity } \\
(k W h)\end{array}$ & 1 & 2 & 3 & 3 & 3 \\
\hline $\begin{array}{c}\text { Discharge } \\
\text { Power }(k W)\end{array}$ & 3 & 2 & 2 & 1 & 3 \\
\hline $\begin{array}{c}\text { Charge } \\
\text { Power }(k W) \\
\end{array}$ & 1 & 2 & 2 & 1 & 3 \\
\hline $\begin{array}{c}\text { Cold temperature } \\
\text { Performance }(k W \& \\
k W h)\end{array}$ & 3 & 2 & 3 & 2 & 1 \\
\hline $\begin{array}{l}\text { Shallow } \\
\text { cycle life }\end{array}$ & 2 & 3 & 1 & 1 & 3 \\
\hline $\begin{array}{c}\text { Deep cycle } \\
\text { life }\end{array}$ & 1 & 3 & 1 & 1 & 2 \\
\hline $\begin{array}{l}\text { Cost }(€ k W-1 \text { or } \\
€ k W h-1)\end{array}$ & 3 & 1 & 1 & 1 & 1 \\
\hline $\begin{array}{c}\text { Abuse } \\
\text { tolerance }\end{array}$ & 3 & 3 & 2 & 2 & 2 \\
\hline $\begin{array}{c}\text { Maturity } \\
\text { Technology }\end{array}$ & 3 & 3 & 2 & 2 & 2 \\
\hline $\begin{array}{c}\text { Maturity } \\
\text { Manufacturing }\end{array}$ & 3 & 1 & 2 & 2 & 1 \\
\hline Recyclability & 1 & 1 & 3 & 2 & 2 \\
\hline
\end{tabular}

$* 1=$ poor; $2=$ fair; $3=$ good

\section{B. Different Vehicles and their Battery Capacity}

\section{1) Hybrid EV}

- Chevrolet Malibu (2016): $1.5 \mathrm{kWh}$

- Ford Fusion II / Ford C-Max II: 1.4 kWh

- Hyundai loniq Hybrid: $1.56 \mathrm{kWh}$

- Kia Niro: $1.56 \mathrm{kWh}$

- Lexus CT 200h: $1.3 \mathrm{kWh}$

- Lexus NX 300h: 1.6 kWh

- Toyota Prius II: $1.3 \mathrm{kWh}$

- Toyota Prius III: 1.3 kWh

- Toyota Prius C / Toyota Yaris Hybrid: 0.9 kWh

- Toyota Camry Hybrid (2012): 1.6 kWh

\section{2) Plug-in Hybrid EV}

- Audi A3 e-tron: $8.8 \mathrm{kWh}$

- Audi Q7 e-tron: $17 \mathrm{kWh}$

- BMW i8: $7 \mathrm{kWh}$

- $\quad$ BMW 2 Series Active Tourer 225xe: 6.0 kWh

- $\quad$ BMW 330e iPerformance: $7.6 \mathrm{kWh}$

- $\quad$ BMW 530e iPerformance: $9.2 \mathrm{kWh}$

- $\quad$ BMW X5 xDrive40e: $9.0 \mathrm{kWh}$

- Chevrolet Volt: 16-18 kWh

- Ford Fusion II / Ford C-Max II Energi: 7.6 kWh

- Fisker Karma: $20 \mathrm{kWh}$

- Honda Accord PHEV (2013): 6.7 kWh

- Honda Clarity PHEV (2018): 17 kWh

- Hyundai Ioniq Plug-in: 8.9 kWh

- Koenigsegg Regera: $4.5 \mathrm{kWh} \frac{[18]}{}$

- Mitusbishi Outlander PHEV: 12 kWh

- Porsche 918 Spyder: $6.8 \mathrm{kWh}$

- Toyota Prius III Plug-in: 4.4 kWh

- Toyota Prius IV Plug-in: 8.8 kWh

- Volkswagen Golf GTE: $8.8 \mathrm{kWh}$

- Volkswagen Passat GTE: 9.9 kWh

- Volkswagen XL1: $5.5 \mathrm{kWh}$

- Volvo V60: 11.2 kWh

\section{3) Battery EV}

- Addax MT: 10-15 kWh

- BMW i3: 22-33 kWh

- BYD e6: 60-82 kWh

- Chevrolet Bolt / Opel Ampera-e: 60 kWh

- Citroen C-Zero / Peugeot iOn (i.MIEV): 14 kWh (2011) / $16 \mathrm{kWh}(2012-)$

- Fiat 500e: $24 \mathrm{kWh}$

- Ford Focus Electric: 23 kWh (2012), 33.5 kWh (2018)

- Honda Clarity (2018): $25.5 \mathrm{kWh}$

- Hyundai Kona Electric: 64 kWh

- Hyundai Ioniq Electric: $28 \mathrm{kWh}$

- Kia Soul EV: 27 kWh

- Luxgen S3 EV+: 33kWh

- Nissan Leaf I: 24-30 kWh

- Nissan Leaf II: $40 \mathrm{kWh}(60 \mathrm{kWh}$ in future option)

- Mitsubishi i-MIEV: $16 \mathrm{kWh}$

- Renault Fluence Z.E.: 22 kWh

- Renault Twizy: $6 \mathrm{kWh}$

- Renault Zoe: 22 kWh (2012), 41 kWh (2016)

- Smart electric drive II: $16.5 \mathrm{kWh}$

- Smart electric drive III: $17.6 \mathrm{kWh}$

- Tesla Model S: 60-100 kWh

- Tesla Model X: 60-100 kWh

- Tesla Model 3: 50-70 kWh

- $\quad$ Toyota RAV4 EV: 27.4 kWh (1997), 41.8 kWh (2012)

- Volkswagen e-Golf Mk7: 24-36 kWh

\section{Specific Power Limitation}

The ability of battery to deliver and accept energy at very high rates is limited by the physical process occurring within the battery cells. When current flows into the battery, the reaction within the cell must occur at a corresponding rate [13]. This means that the dynamics of the reaction at the 
electrode surface and the transport of ions (kinetic properties) must occur at the same rate as the supplied current. Because of the high currents associated with high power, the reaction rate is unable to match the rate at which current is being supplied. As a result, the capacity of battery is reduced and joule heating occurs within cell.

\section{Specific Energy Limitation}

The restricted energy content of batteries is one of the major drawbacks limiting the successful implementation of EV technology. Considering the specific energy of gasoline is $9.2 \mathrm{kWhkg}-1$ corresponding to more than $3 \mathrm{kWhkg}-1$ useful specific energy ${ }^{[14]}$, limitations of the battery powered EV become apparent. Two emerging battery technologies addressing the specific energy limitations are lithium air ( $\mathrm{Li}$ air) and lithium flour (Li-flour).

\section{E. Hybrid Energy Storage}

One method of achieving electrical energy storage with a high specific power is to use ultra-capacitors (UC) ${ }^{[15]}$. The use of UC's alone would not suffice, as these components display poor specific energy characteristics. The ideal solution is to use a hybrid energy storage method in a parallel configuration as shown in the figure. This type of set up combines the high specific power density of UC's with the higher specific energy of an electrochemical battery (B).

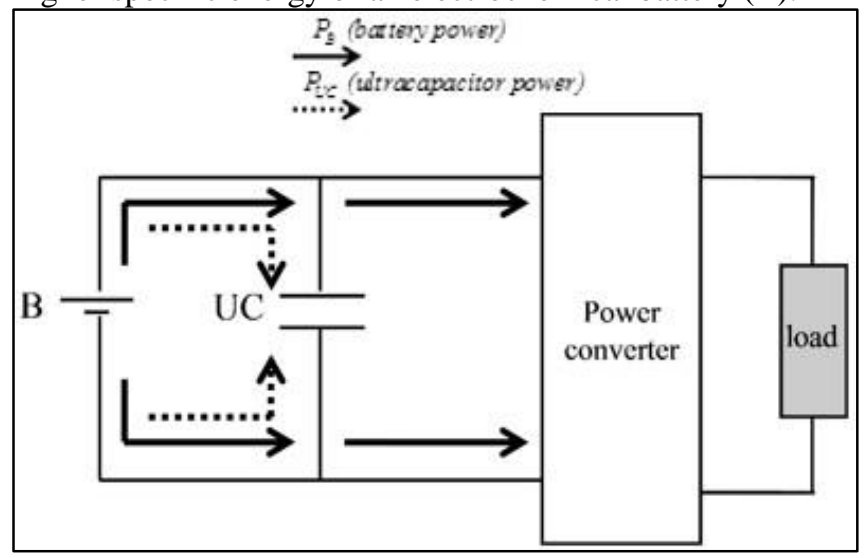

Fig. 2: The case for a low power demand, where $\mathrm{B}$ is able to charge the UC

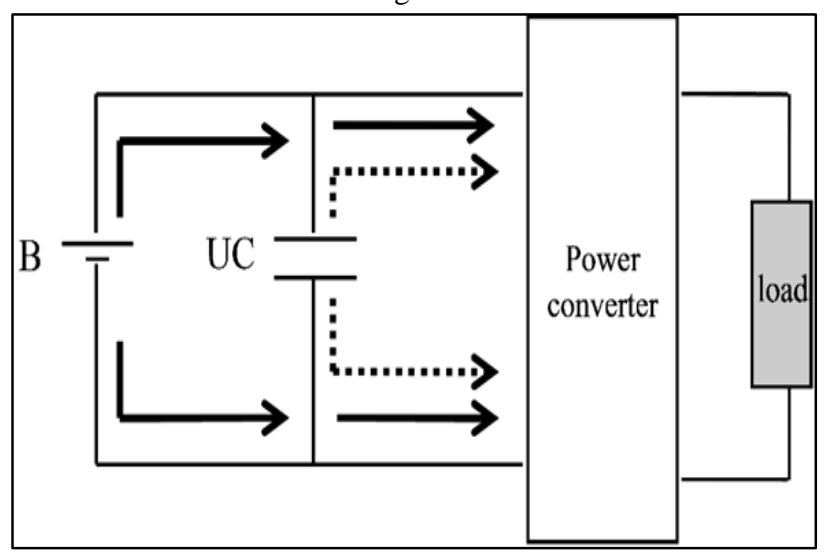

Fig. 3: The case where a higher power is demanded and both $B$ and UC contribute to the total power supply

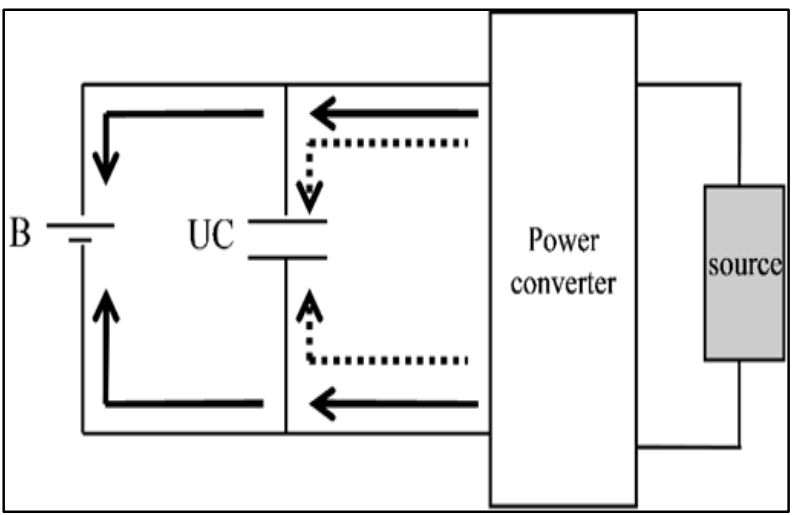

Fig. 4: The case for both energy storage sources can be recharged using regenerative braking

This type of configuration is however costlier, due to the additional components and the additional complexity in controlling and managing both power sources. This cost could be offset by selecting a battery technology which has high specific energy, as specific power is no longer a requirement to fulfil.

\section{F. Battery Lifetime}

Predicting the aging effects of individual cells, and therefore battery lifetime, is a complex task, but crucial if the reliability and usability of EV's is to be improved. According to Troltsch et al ${ }^{[16]}$, the main aging mechanism is the growth of a surface film, also known as the solid electrolyte interface (SEI), on the negative electrode. Other physical effects occur over time, which affect the conductivity of the electrolyte and hence increase the internal resistance. The net effect is a decrease in battery capacity over time. The lifetime of the battery is the time whereby the battery capacity is above a minimum accepted capacity. As described in Handbook of Batteries ${ }^{[17]}$, this lifetime depends on the depth of discharge (DOD), the number of cycles and the age.

\section{G. State of Health}

The state of health $(\mathrm{SOH})$ of a battery system is a term used to describe the energy content of the battery after consideration of aging effects. In terms of $\mathrm{EV}$ performance, relating the State of Charge (SOC) to the $\mathrm{SOH}$ provides a more accurate indication of the energy remaining in the battery and thus a more accurate fuel gauge to the driver. This concept is explained with reference to the Table below. Assuming an energy usage of $0.2 \mathrm{kWh} / \mathrm{km}$ and a battery with a capacity of $30 \mathrm{kWh}$, a range of $150 \mathrm{~km}$ is achieved. However, as the battery ages and the capacity decreases, the range decreases. If the battery energy indicator does not consider this aging effects, the EV will have a shorter range than predicted.

\begin{tabular}{|c|c|c|}
\multicolumn{2}{|c}{ Table 5: Effect of Battery Age on SOH } \\
\hline Age & $\begin{array}{c}\text { SOH } \\
\text { (\% of capacity) }\end{array}$ & Range $(\mathrm{km})$ \\
\hline $\begin{array}{c}\text { Beginning of Life } \\
(\text { BOL) }\end{array}$ & 100 & 150 \\
\hline $\begin{array}{c}\text { Middle of Life }(\mathrm{MOL}) \\
\text { End of Life }(\mathrm{EOL})\end{array}$ & 90 & 135 \\
\hline
\end{tabular}




\section{H. Battery Management System}

Batteries for electric vehicles consist of many interconnected cells in combination forming a battery pack. Individual battery cells a show a reduction in capacity with increasing charge and discharge cycles, as well as variations in temperature. When cells are connected in a series or parallel configuration as in a battery pack, management and control of the charge and discharge conditions becomes crucial to extend the lifetime and limit ageing effects of individual cells. A battery management system (BMS) is used to monitor, control and balance the pack. The main functions of a BMS are outlined in the figure below. Without balancing the battery pack, the battery is not only risking unnecessary damage, it is also operating sub-optimally. Because the worst cell is limiting the performance of all cells in the battery pack, it is very important to prevent big differences in cell's state of charge.

The cost and complexity of a BMS depends on the functionality and intelligence built into the management system. State-of-charge (SOC) estimation is an important parameter to measure accurately, especially if EV's are integrated with a smart electrical grid. Different methods of estimating SOC are detailed in Battery Management Systems: Accurate State-of-Charge Indication for BatteryPowered Applications ${ }^{[18]}$.

Because the performance of battery cells varies with temperature, it is therefore crucial to include a thermal management

system in the battery pack. This ensures all cells are both electrically and thermally balanced and the lifetime will be extended. Thermal management systems can either use air or liquid as the transfer medium. For integrating into the vehicle, the power consumption must be low and it must not add much additional mass. The thermal management system can realize its performance requirements using either passive or active means. A passive system using only the ambient environment may provide sufficient thermal control for some battery packs whereas active control may be required for others.

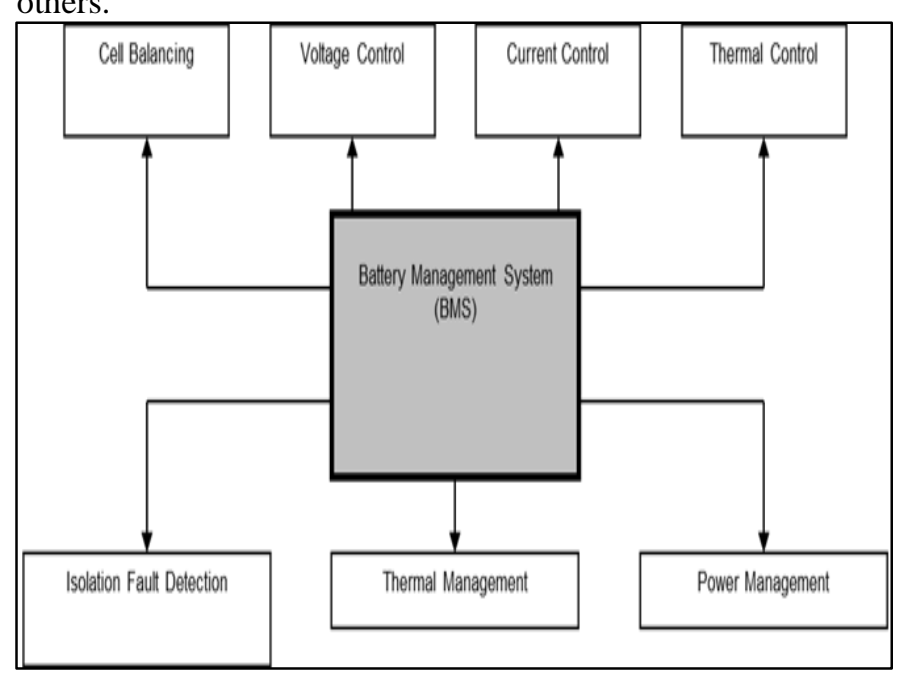

Fig. 5: Battery Management

To understand the importance of the battery management system, we take a closer look inside. The BMS has the possibility to monitor and

control (directly or

indirectly) several

different parameters

of the battery: 1)

Voltage

2) Current

3) State of Charge

4) Temperature

5) State of Health

First of all, the voltage of the total battery pack and of the individual cells are monitored by the BMS. The BMS can keep track of the difference between the minimum and the maximum cell voltages, and estimate if there is a dangerous imbalance in the battery pack. The charging and discharging current of the battery pack is essential to control, as too high current can overheat a battery and lead to a failure. Further, improper control of the charging and discharging current can lead to overvoltage and under voltage of the battery, respectively that can harm the battery on the long run.

The state of charge function is extremely important to keep track on, because many batteries must not be discharged below a certain percentage. This is because, if the depth of the discharge becomes too high, some batteries can start to break down or lose their capacity. The state of charge can be determined from the measured values of the voltages and currents.

Another function is the temperature of the battery pack and the individual cells. Temperature is directly related to the battery lifetime; as high temperatures can degrade the battery faster. The individual cell temperature is important to know as well, to see if there are local hot spots, indicating a possible failure. Using the BMS together with the battery thermal management system can cool the battery and keep it within a nominal range. When there is a coolant available, the temperature of the intake and output coolant temperature is an important indicator of the temperature of the battery pack.

The state of health is a measurement to estimate the overall condition of the battery with respect to lifetime. Battery cell balancing is key feature of the BMS to help increase battery lifetime. Naturally after a while, the different cells in a battery pack will start to show differences in the state of charge and thus show localized under or overcharging. This can have multiple causes. For example: manufacturing inconsistencies, different charging/discharging currents, heat exposure and more. This is detrimental to the lifetime of the battery pack, because most cells in the battery pack are connected in series (adding voltages). This means that if 1 battery cell breaks down, the whole battery pack will seem to be broken (zero current). The BMS can perform balancing in a passive or active way. In case of passive cell balancing, passive elements such as resistors are used. This is simple but inefficient as it leads to power losses in the resistors. On the other hand, in case of active balancing, DC-DC power electronic converters are used to equalize the cells and reduce the differences between the operational state of individual cells. 


\section{Li-ion and $B M S$}

Almost all electric vehicle battery systems are made with the lithium-ion battery chemistry. Lithium-ion rechargeable batteries are more sensitive to imbalance than other battery chemistries. This is because lithium battery chemistries are more susceptible to chemical damage, like cathode fouling, molecular breakdown and unwanted chemicals from side reactions. The chemical damages will occur quickly in lithium-ion batteries when slight over voltages or over currents are applied. Heat accumulation inside the battery pack can accelerate these unwanted chemical reactions.

Lithium battery chemistries often permit flexible membrane structures, which makes it possible to use lightweight sealed bags, improving the energy density and specific energy of the battery. Some unwanted chemical reactions that occur when the battery is mistreated, will result in gaseous by-products. This leads the batteries to become 'puffy' or 'balloon-like', which is a strong indicator of a failed battery. The big danger in lithium-ion batteries is the accumulation of pressure, which can lead to an explosion. The organic electrolyte contains hydrocarbon chemicals which are flammable, leading to a dangerous cocktail upon battery failure. This illustrates why a proper battery management system is crucial for lithium-ion batteries.

\section{J. Techniques to Improve Battery Life}

It is clear that the BMS, through balancing, thermal management and control of voltage and current helps in improving the battery life. Another important factor that can improve battery life is to reduce the number of chargedischarge cycles and the maximum depth of discharge. The battery should not be completely charged and discharged, because this is detrimental to battery life. Furthermore, some $\mathrm{EV}$ manufacturers let their customers set the maximum percentage until which the battery should be filled for everyday use, and they recommend a rather low setting of around $80 \%$, which can be increased for longer trips.

Another setting in EVs which is sometimes available is the option to limit the power output of the car. This has the downside of having lower acceleration, but it limits the discharge rate of the battery, and therefore is less detrimental to the battery.

\section{Charging of evs}

The most common source of charging of EVs are the power grids. Other small source of power like solar cells, wind power or hydro power also can be used to charge the EV batteries. Charging time is commonly restricted by the capability of the grid association. a standard home outlet delivers one.5 kilowatts (in the U.S., Canada, Japan, and different countries with a hundred and ten $\mathrm{V}$ supply) and three kilowatts (in countries with $240 \mathrm{~V}$ supply). In 1995, some charging stations charged BEVs in one hour. In Nov 1997, Ford purchased a fast-charge system created by AeroVironment known as "PosiCharge" for testing its fleets of Ranger EVs, that charged their lead-acid batteries in between six and fifteen minutes. In Feb 1998, General Motors declared a version of its "Magne Charge" system that may recharge NiMH batteries in concerning 10 minutes, providing a variety of sixty to 1 hundred miles [19]. In 2005, handheld device battery designs by Toshiba were claimed to be able to accept an $80 \%$ charge in as little as 60 seconds [20]. Scaling this specific power characteristic up to a similar seven kilowatt-hour work unit pack would lead to the requirement for a peak of 340 kilowatts of power from some supply for those sixty seconds. it's not clear that such batteries can work directly in BEVs as heat build-up could create them unsafe. Electric cars like Tesla Model S, Renault Zoe, BMW i3, etc. will recharge their batteries at fast charging stations inside half-hour to eighty percent [21] [22] [23] [24]. Scientists at Stanford University in California have developed a battery that can be charged within one minute. The anode is made of aluminium and the cathode made of graphite [25] [26]. The electric car Volar-e of the company Applus + IDIADA, based on the Rimac Concept One, contains lithium iron phosphate batteries that can be recharged in 15 minutes [27]. According to the manufacturer BYD the lithium iron phosphate battery of the electric car e6 is charged at a fast charging station within 15 minutes to $80 \%$, after 40 minutes at $100 \%$ [28].

The three common ways to charge EVs are:

1) Conductive

Charging - AC

and DC

2) Inductive

Charging

Static and

Dynamic 3)

Battery swap

technology

The physical location of the components for converting the power supplied by the grid to that required by vehicle battery can be categorized as on-board and off-board chargers. Onboard chargers are located within the vehicle, and the size and power rating are constrained by the available space within the vehicle. Off-board chargers are located outside the vehicle, and this setup provides more flexibility in terms of the power that can be delivered. Both classes of charging devices must contain control circuits and communicate in real-time with the vehicle battery. This is to ensure that the battery is charged in an optimum way, avoiding any damage to the battery through overcharging. AC charging uses an onboard charger while DC and battery swap use an offboard charger. In case of an inductive charger, a combination of both an on-board and off-board charger are required.

\section{A. Conductive Charging}

This is the most common

charging method right now

and it has 2 categories: $\mathrm{AC}$

and DC charging. 1)

Conductive Charging - AC 


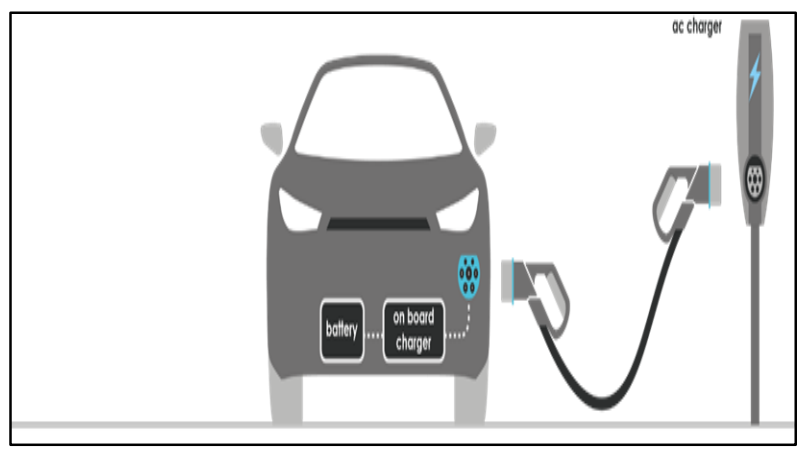

Fig. 6: AC Conductive Charging

- Advantages

1) The battery can be recharged anywhere using the AC grid and the on-board EV charger

2) The EV charger can easily communicate with the Battery Management System (BMS) and no additional power electronic converters are needed in the EV charger. This leads to a higher performance and lower - Disadvantages

1) $\mathrm{AC}$ power has to be converted into $\mathrm{DC}$ power in the car, and there is a limitation of the power output for $\mathrm{AC}$ charging due to size and weight restrictions of the onboard charger

2) AC charging needs relatively long time due to the relatively lower charging power

\section{2) Conductive Charging - DC}

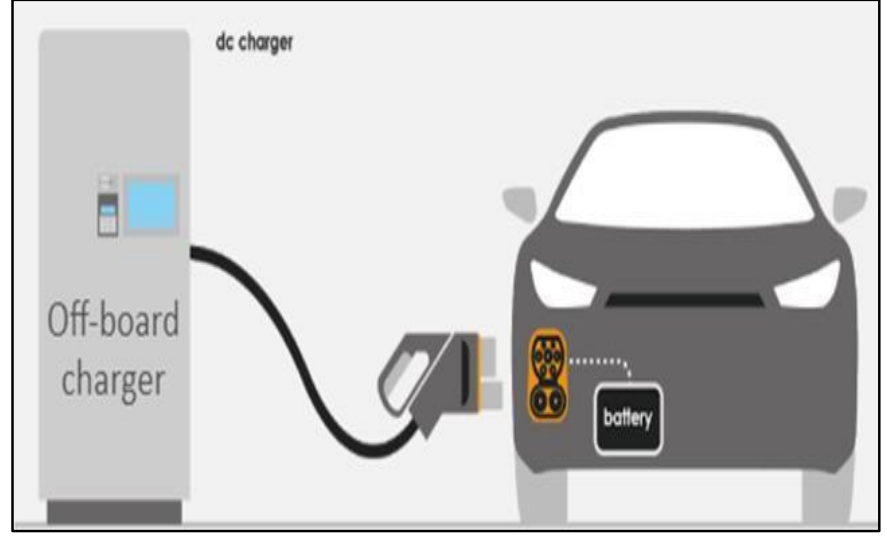

Fig. 7: DC Conductive Charging

DC charging is suitable for high power EV charging, and the power output of fast charges is limited only by the ability of the batteries to accept the charging power.

\section{- Advantages}

1) It can be designed with either a high or low charging rate, and is not limited in its weight and size. 2) DC charging with high power requires low charging time. - Disadvantages

1) Higher investment for installation of the charger when compared to AC charging.

2) Adverse impact on power system: high power demand on the grid esp. at peak hours

3) Since the off-board chargers and the BMS are physically separated, reliable communication is important to ensure correct charging conditions.

\section{B. Inductive Charging}

Inductive charging also has two categories: Static \& Dynamic

\section{1) Static Inductive Charging}

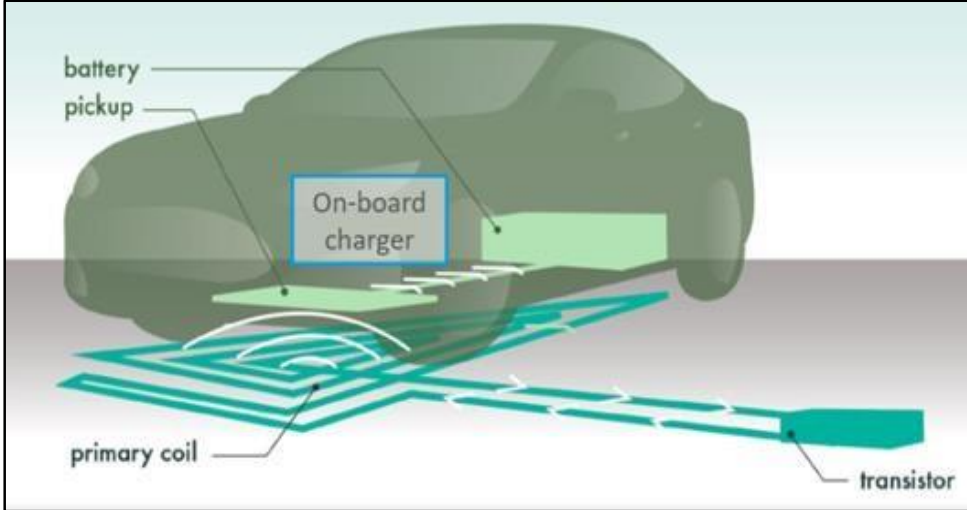

Fig. 8: Static Inductive Charging

The main idea behind inductive charging is the use of two electromagnetically linked coils. The primary coil is placed on the road surface, in a pad-like construction linked to the electricity network. The secondary coil is placed on the vehicle, ideally on the bottom or top of the car. The $50 \mathrm{~Hz} \mathrm{AC}$ power from the grid is rectified to $\mathrm{DC}$ and is then converted to a high-frequency AC power within the off-board charger station. Then this high-frequency power is transferred to the EV side by electromagnetic induction. The coils on the car convert this high-frequency AC power back to DC to charge the EV using the on-board charger.

- Advantages

1) Convenience

2) Suitable for self-driving cars

- Disadvantages

1) High investment

2) Limited space \& weight of charge pads

3) Misalignment tolerance between the vehicle and the charge pad

4) Power losses and relatively lower efficiency than conductive charging

5) Electromagnetic radiation exposure

\section{Dynamic Inductive}

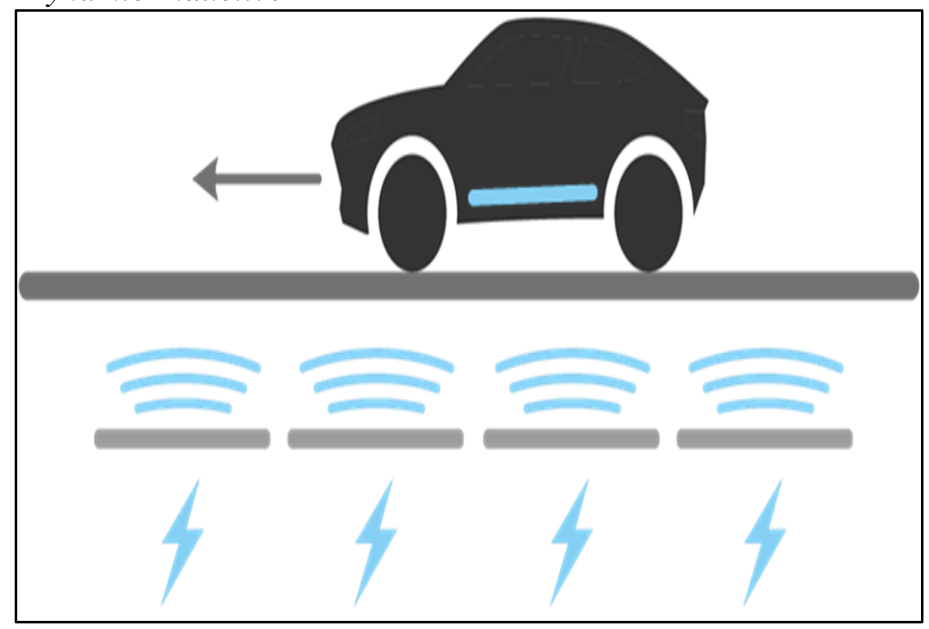

Fig. 9: Dynamic Inductive 
The other way to charge a car wirelessly is called dynamic charging. The coils connected to electric cables which used to provide the power are buried in the road. The coils emit an electromagnetic field that is picked up by vehicles driving over them and converted into electricity to charge the cars.

1) Low stand-in charging time

2) Low battery DoD

3) Smaller battery size

So far the dynamic inductive charging is still in the experimental stage because there are many challenges to standardize it. The challenges are:

1) The high cost of investment

2) Foreign objects, coil structure changes and coil misalignment on the road

3) Applicability of different car types and universal coil

type selection

\section{Battery Swap}

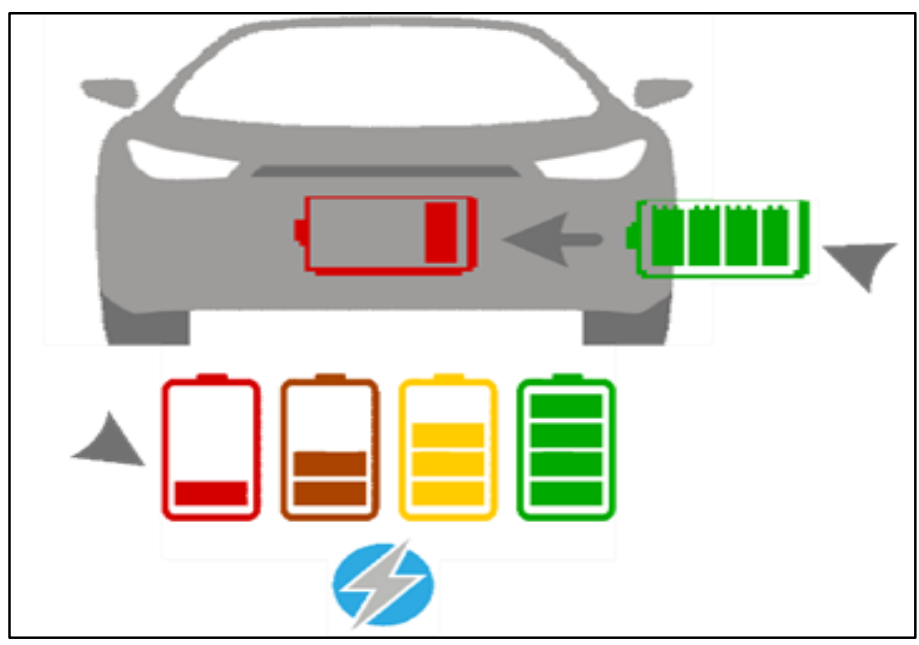

Fig. 10: Battery Swap

The third method of EV charging is battery swap. It works on the basis of switching out the depleted battery and replacing the same with a full battery. The process involves driving into a battery switching bay and an automated process will position the vehicle, switch out the current battery and replace it with a fully charged battery. The depleted batteries are charged in the station for later deployment. The system works on the business concept that the EV user owns the vehicle and not the battery. Battery swap requires a fool proof way to estimate the batteries state of health to check for its usage pattern and to ensure that only authorized vehicles and charging stations can charge it.

- Advantages

1) No range anxiety

2) Quick and easy refilling like a combustion engine car tank

3) Longer charging times available for the EV battery compared to fast DC charging - Disadvantages

1) The requirement of standardized battery interface across multiple car manufacturers.

2) Consumer acceptance of not owning a battery and having to change the vehicle battery.
D. Comparison of EV Charging Methods

\begin{tabular}{|c|c|c|c|c|c|}
\hline \multirow{2}{*}{$\begin{array}{l}\text { Battery } \\
\text { powering } \\
\text { methods }\end{array}$} & \multicolumn{2}{|c|}{ Conductive charge } & \multicolumn{2}{|c|}{ Inductive charge } & \multirow{2}{*}{ Battery swap } \\
\hline & $A C$ & $D C$ & Static & Dynamic & \\
\hline Convenience & 0 & $\theta$ & $\infty$ & see & $\theta e$ \\
\hline Cost & $\varepsilon$ & $\epsilon €$ & EE $\sim E E$ & ceeceE & $\ell$ \\
\hline Service time & $\begin{array}{l}\text { Relatively } \\
\text { long }\end{array}$ & Veryshort & $\begin{array}{c}\text { Relatively } \\
\text { long }\end{array}$ & Veryflexible & Shortest \\
\hline Power level & $N N$ & NNNN & $N \sim N N$ & $N N \sim N N N$ & $N \sim N N N$ \\
\hline Efficiency & 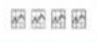 & 网两胡 & 网网 & 因 & 可前同因 \\
\hline Battery lifetime & (1)(0) & (1) () & $0(0)$ & 00000 & () \\
\hline Impact on grid & " $\approx$ & mu! & u & $\mathbf{u}^{2} \mathbf{u}$ & "u! \\
\hline $\begin{array}{l}\text { Standardization } \\
\text { challenge }\end{array}$ & (1) & (1) & (1) & (1)(1)(1) & (1)(1) \\
\hline
\end{tabular}

Fig. 11: EV Charging

Overall comparison of these batteries are as follows:

- It can be observed that the dynamic inductive charging is the most convenient charging method but also the most expensive. Even if the static inductive is cheaper compared to the dynamic one, the average cost of inductive charging is higher than any other method. Dynamic inductive charging has the most flexibility as the car can be charged at any time when on the way and do not need to stop by the service point.

- To power the battery, the battery swap method needs the shortest serving time. For all charging methods except battery swap, the serving time is highly related to the power level. In this case, the DC conductive charging method has the highest power capacity among all the methods.

- There are many factors that impact the efficiency, e.g. the number of power converters and their types, the charging power, and the charging methods. From the table, we can see that, in general, the conductive charging method has higher overall efficiency than inductive charging. It is because the power conversion process using an air gap is less efficient than direct power transfer using cables. Further, the efficiency of inductive charging reduces as a result of the misalignment between the sending and receiving charge pads.

- The battery lifetime is depending on many factors, for example, the charging power (C-rate) and the DOD. The battery lifetime in DC charging has the lowest lifetime because the charging power and hence the corresponding $\mathrm{C}$-rate are the highest. Further, typically at fast charging stations, people want to charge their batteries as much as possible for long distance trips increasing the depth of discharge as well. In contrary, batteries operated with dynamic inductive charging method has the longest lifetime expectations because the batteries can be charged/discharged with small DOD.

- From the perspective of grid impact, the DC charging method has the most significant impact since it has the highest power level. Besides, the battery swap could 
also have a high impact on the grid if the charging powers are high as well.

- Finally, considering standardization challenge, the dynamic inductive charging and the battery swap are faced with the most difficult challenges. It is because both methods require standardization between car types, battery size, power level and even shape.

\section{E. AC Charging}

AC charging allows EVs to be charged by using inexpensive AC charging stations which feed AC power directly from the grid to the car. The nature of AC, that is, single phase or three phase, voltage level and grid frequency may vary from country to country. AC charging uses an on-board charger to convert $\mathrm{AC}$ power from the conventional $\mathrm{AC}$ grid to direct current or DC power to charge the traction battery. Cars have a standardised vehicle inlet, and a charging cable is used for connecting the vehicle connector to the infrastructure socket of the AC charging station. The on-board charger needs to be light (typically less than $5 \mathrm{~kg}$ ) and compact due to the limitation of allowable payload and space in the EV and the PHEV. The drawback of this charger is the limitation of the power output because of size and weight restrictions.

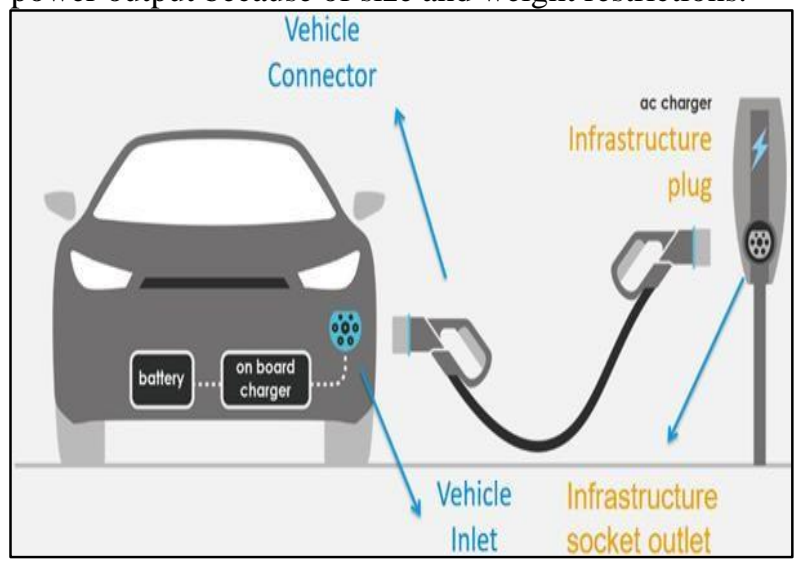

Fig. 12: AC Charging of EVs

\section{AC Charger}

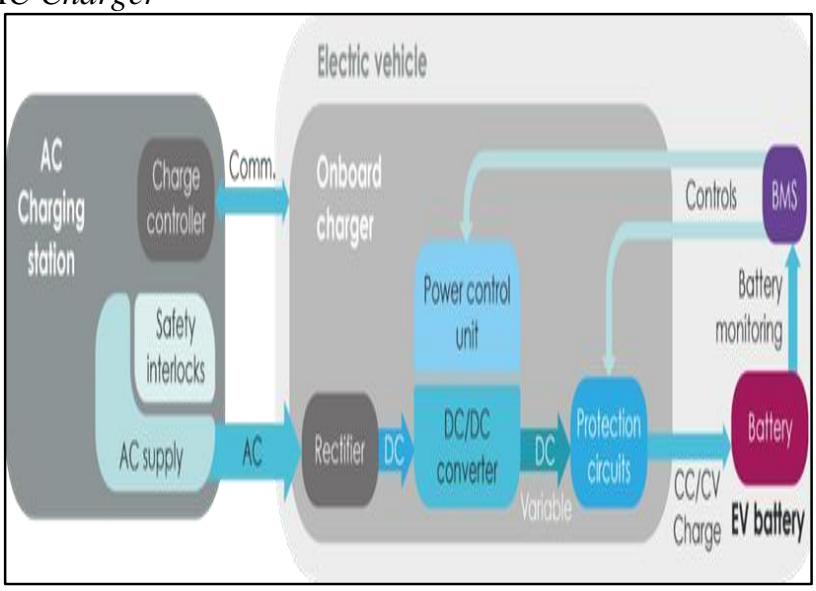

Fig. 13: Operation of

- When the charging station and the EV are first connected, the charge controller in the station communicates with the EV. Information regarding the connectivity, fault condition and current limits are exchanged between the charger and the EV.
- When the AC power is provided to the EV, the on-board charger has a rectifier that converts the $\mathrm{AC}$ power to $\mathrm{DC}$ power. Then, the power control unit appropriately adjusts the voltage and current of a DC/DC converter to control the charging power delivered to the battery.

- The power control unit, in turn, gets inputs from the Battery Management System or the BMS for controlling the battery charging.

- Apart from this, there is a protection circuit inside the on-board charger. The BMS triggers the protection circuits if the battery operating limits are exceeded, isolating the battery if needed.

\section{2) AC Charging Types}

The EV industry has not agreed on one specific AC connector, so depending on the car brand and country, the connector varies in shape, size and pin configuration. One of the main reasons is the difference in AC voltage and frequency. Generally, an AC connector has two or more larger pins to transmit power, and some smaller pins for communication. Four types of AC connectors are used worldwide, namely:

- The Type 1 connector, which is mostly used in USA \& Japan

- The Type 2 connector, which is mostly used in Europe, including those of Tesla cars

- The Type 3 connector, used in Europe but is being increasingly phased out by Type 2 connectors

- The proprietary connector used by Tesla for its cars in the USA

- China has its own standard for AC charging, which is similar to Type 2 connectors.

a) Type 1

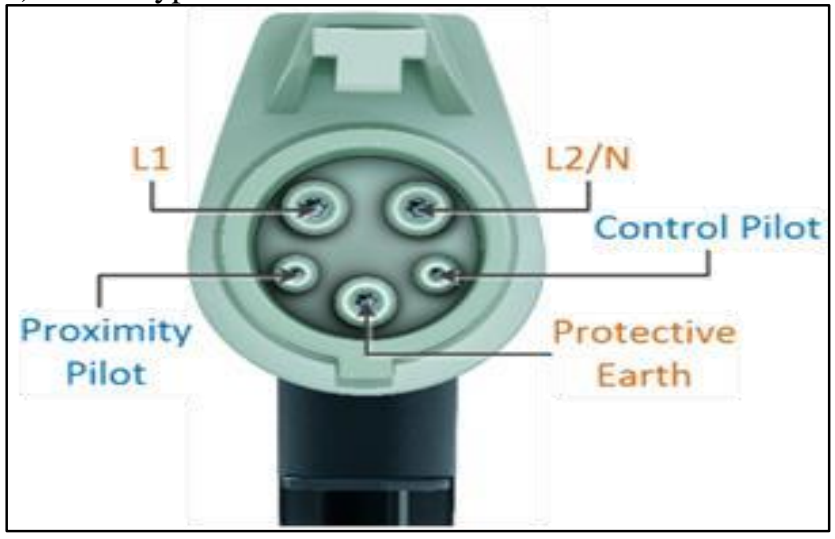

Fig. 14: Type 1 AC Charger connector

\section{- Brief History and Usage Information}

SAE International proposed a standardized coupling coupler (SAE J1772-2001) based on a design approved by the California Air Resources Board for charging stations of EVs. This rectangular plug was based on a design by Avcon. In 2009, a modification of this design with a round housing was published by Yazaki and the SAE J1772-2009 coupler specifications were included to the IEC 62196-2 standard as an implementation of the Type 1 connector for charging with single-phase AC. This connector is used for charging mostly in USA and Japan and it is popularly known as the Yazaki or J1772 connector. 


\section{- Pin Configuration}

It is used specifically for charging with single-phase AC. It has a round housing consisting of five pins $-2 \mathrm{AC}$ wires, earth wire and two signal pins. The two signal pins are the proximity detection pin used for ensuring connectivity between the EV and the charger, and the control pilot for control of charging. - Maximum Voltage and Current Ratings Voltage $120 \mathrm{~V}$ or $240 \mathrm{~V}$; Current up to $80 \mathrm{~A}$.

b) Type 2

Brief History and Usage Information

The type 2 connector was tested and standardized first by the German Association of the Automotive Industry (VDA) as VDEAR-E 2623-2-2, and thereafter recommended for use by the European Automobile Manufacturers Association (ACEA) in 2011. The European Commission too recommended this charger for use across the whole of Europe in early 2013. The connector is circular in shape, with a flat top edge. It has been ergonomically designed such that it can be operated with one hand. Cars have a standardized male inlet while the female outlet is fitted to the charging station. The Chinese AC charger is similar to the type 2 connector. Tesla uses the Type 2 connector in Europe for both AC and DC charging.

\section{- Pin Configuration}

The connector consists of two small signal pins for control and proximity pilot and five big pins, which combine both $\mathrm{AC}$ and DC charging in one single connector. The five power pins are used for Neutral (N) and line phases (L1, L2, and L3) and Protective earth (PE). The connector can hence be used for both single and three phase AC charging.

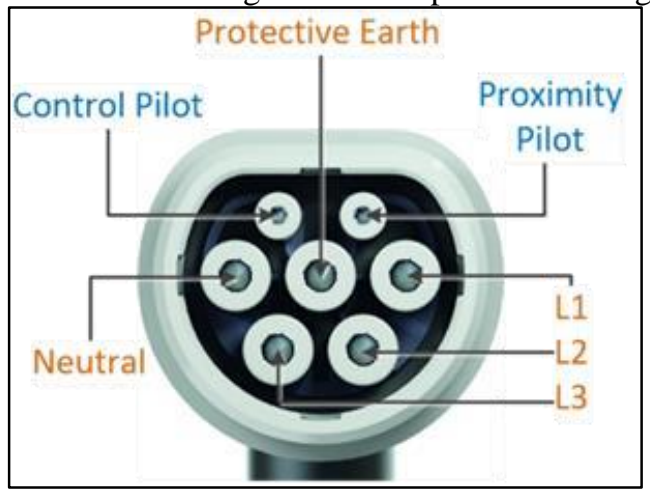

Fig. 15: Type 2 AC Charger connector

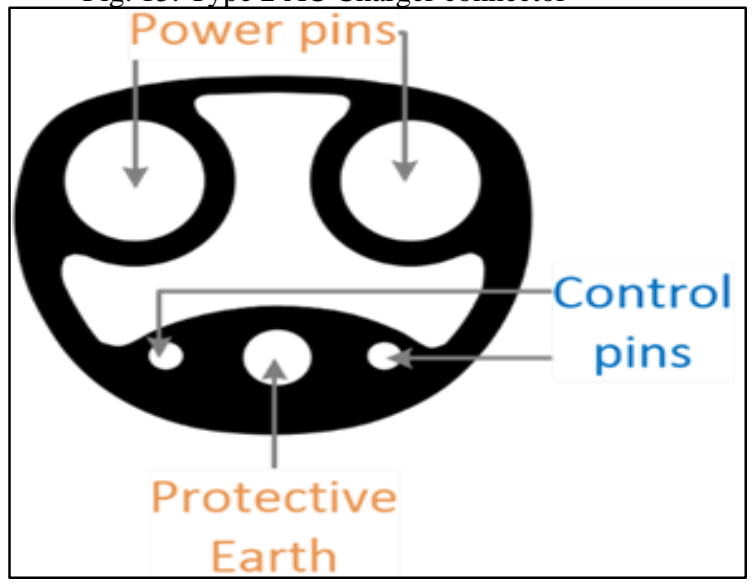

Fig. 16: Tesla US Charger connector

- Brief History and Usage Information
Proprietary connectors are used in the USA for Tesla AC charging and DC charging. Has an adapter than help the connector to be used with Type 1 AC charging stations and Chademo DC charging stations.

\section{- Pin Configuration}

The connector consists of two small signal pins for control and three bigger power pins, which combine both $\mathrm{AC}$ and DC charging in one single connector. The three power pins are used for Neutral (N) and line phase (L1) and Protective earth (PE). The connector can be used only for single phase AC charging and not for three phase. Tesla uses the same connector for DC charging as well.

- Maximum Voltage and Current Ratings

1 Max charging power of $17.2 \mathrm{~kW}$ when connected to $240 \mathrm{~V}$ AC outlet.

\section{3) Control and Proximity Pilot}

- The Type 1 and Type 2 connectors have 2 common communication pins: the Control Pilot $(\mathrm{CP})$ and the Proximity Pilot (PP).

- The Proximity Pilot (PP) checks if the vehicle connector is connected properly to the vehicle inlet. If the connection is not properly established, the Proximity Pilot will detect it, and the entire process will be disabled for safety.

- The second special pin is the control pilot (CP), and it is used for controlling the charging current. The control pilot continuously sends a pulse width modulated or PWM signal to the car. In this way, it tells the car the maximum current that can be drawn from the charging station, Imax. The car then can draw the desired current Iac , as long as this value is smaller than the maximum current Imax.

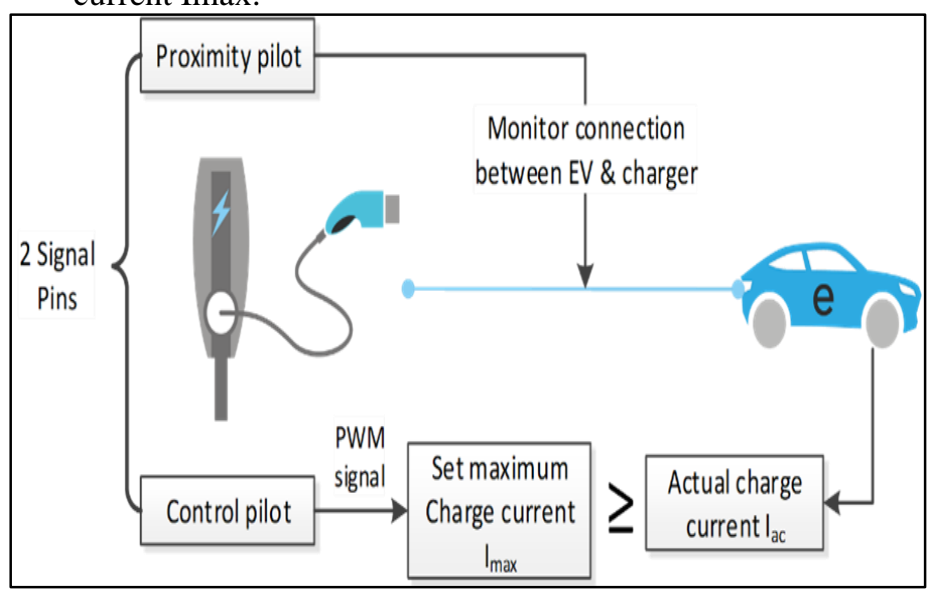

Fig. Working of Control \&

\section{4) Fast on-board AC Chargers}

AC charging typically needs an on-board AC/DC power converter. Quite interestingly, the motor and the motor drive inverter which converts the DC power from the battery into $\mathrm{AC}$ power for the motor can also be used as the on-board charger for the battery for AC/DC conversion. This eliminates the need for a separate AC/DC power converter for the on-board charger. Since the drivetrain power converter is usually high power $>100 \mathrm{~kW}$, this also means that the EV can reach quite high charging rates $>22 \mathrm{~kW}$. The challenge is to design the motor drive and its control tp 
rovide the dual functionality of EV charging when stationery and $\mathrm{EV}$ propulsion when in motion.

An excellent example of this implementation is the Renault ZOE EV which provides $43 \mathrm{~kW}$ on-board AC fast charging. The Renault has claimed to use a junction box that helps in modifying the operation of the motor and motor drive components to be used as an on-board EV charger.

\section{5) Calculating the AC Charging Power}

Given a value of the charging power required to charge a battery and the AC grid voltage, we can estimate the charging current required. Assuming a power factor of unity and neglecting all losses, we come up with the following relations for power:

Single phase: $\mathrm{P}_{\mathrm{ch}}=\mathrm{V}_{\mathrm{ac}} \mathrm{I}_{\mathrm{ac}}$

Three phase: $P_{c h}=\sqrt{3}\left(V_{3 a c} I_{a c}\right)=3 V_{a c} I_{a c}$, where, $V_{a c}$ is the single-phase $\mathrm{AC}$ voltage $(\mathrm{V}), \mathrm{V}_{3 \mathrm{ac}}$ is the three-phase line-toline $\mathrm{AC}$ voltage $(\mathrm{V}), \mathrm{P}_{\mathrm{ch}}$ is the charging power $(\mathrm{W}$ or $\mathrm{kW})$ and $\mathrm{I}_{\mathrm{AC}}$ is the grid current (A).

If the phase voltages are given for a system, just multiply it by a factor of $3^{0.5}$ to get the line to line voltage.

\section{6) Calculating the Charging Time and Power}

Given a value of the charging power required to charge a battery and the AC grid voltage, we can estimate the charging current required. Assuming a power factor of unity and neglecting all losses, we come up with the following relations for power: $E_{b a t t}=\mathrm{P}_{c h} * t_{c h} t_{c h}=$ Ebatt $/ \mathrm{P}_{c h}$, where, $\mathrm{P}_{\mathrm{ch}}$ is the charging power (W or $\mathrm{kW}$ ), is the charging power (hour) and is the energy delivered to the battery (kWh).

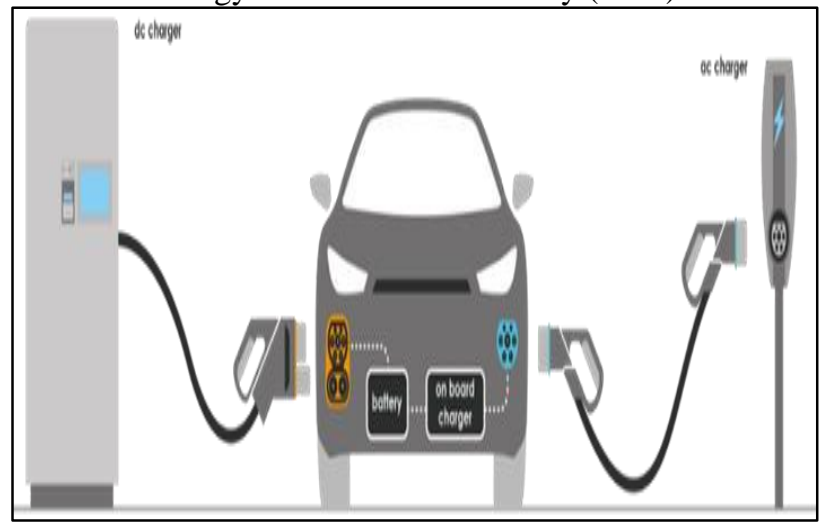

Fig. DC charging of

\section{F. DC Charging}

DC Fast Chargers supersede Level 1 and Level 2 charging stations and are designed to charge electric vehicles quickly with an electric output ranging between $50 \mathrm{~kW}-350 \mathrm{~kW}$.

With high power operation, the AC/DC converter, the DC/DC converter and the power control circuits become larger and more expensive. That is why DC fast chargers are implemented as an off-board charger rather than as an onboard charger so that it does not take up space within the vehicle and the fast charger can be shared by many users. 1) DC Charger Operation

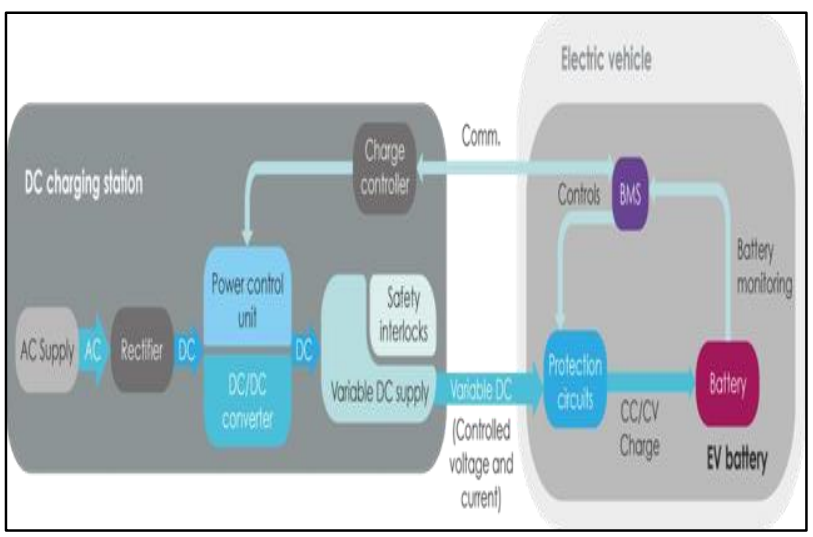

Fig. 19: Operation of DC chargers

- In the first step, the alternating current or AC power provided by the $\mathrm{AC}$ grid is converted into direct current or DC power using a rectifier inside the DC charging station.

- Then, the power control unit appropriately adjusts the voltage and current of the DC/DC converter inside the charging station to control the variable DC power delivered to charge the battery.

- There are safety interlock and protection circuits used to de-energize the EV connector and to stop the charging process whenever there is a fault condition or an improper connection between the EV and the charger.

- The battery management system or BMS plays the key role of communicating with the charging station to control the voltage and current delivered to the battery and to operate the protection circuits in case of an unsafe situation.

\section{2) Types of DC Charger Connectors}

There are five types of DC charging connectors used globally:

1) The CCS-combo 1, which is mainly used in the US,

2) The CCS-combo 2, which is mainly used in Europe,

3) The Chademo connector, used globally for cars built by Japanese automakers.

4) The Tesla DC connector, which is used for AC charging as well

5) And finally, China has their own DC connector, based on the Chinese GB/T standard.

1) $\mathrm{CCS} / \mathrm{Combo} 1 \& \mathrm{CCS} / \mathrm{Combo} 2$

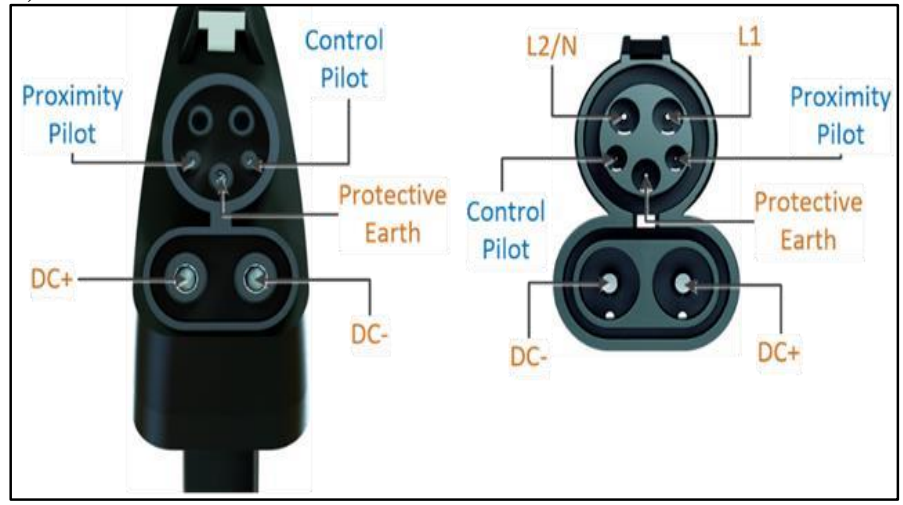

Fig.20:CC\$Combo 1 


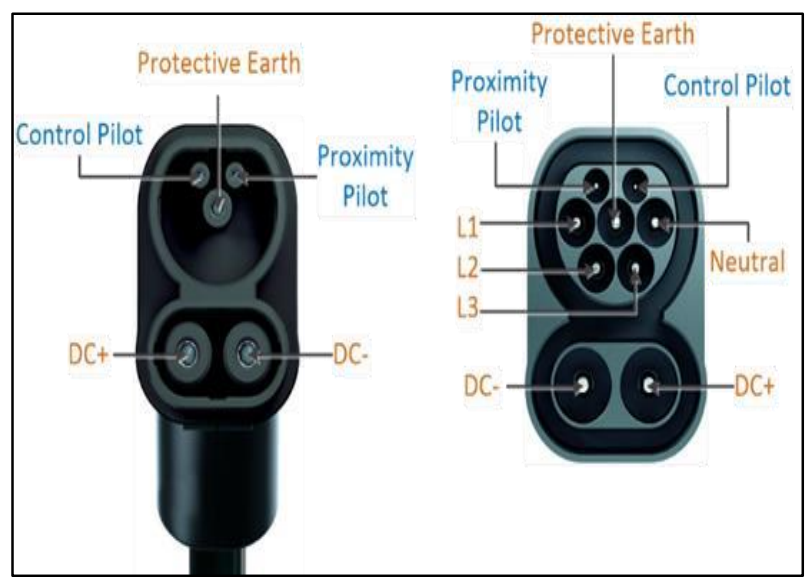

Fig. 2 1CCS/Combo

- Brief History and Usage Information

The Charging Interface Initiative e. V. - abbreviated to CharIN e. V. - is a registered association founded by Audi, BMW, Daimler, Mennekes, Opel, Phoenix Contact, Porsche, TÜV SÜD and Volkswagen. CharIN association is the driving force behind the Combo connector. The key features of the Combined Charging System are the use of a single connector for both AC and DC charging by using separate pins within the same connector. The Combo AC and DC charging connector comply with the IEC 62196-1, IEC 62196-2 and IEC 62196-3 standards. The signalling and communication for AC charging is compliant with IEC 61851-1, 6185122, and for DC charging with IEC 61851-1, 61851-23, ISO/IEC 15118, the German DIN SPEC 70121 and the SAE J2847/2 standards. So the control pilot has both low-level communication using PWM and high-level communication using power line communication (PLC) [29]. - Pin Configuration

Here you see the Combo 1 and Combo 2 vehicle connector is on the left side, and the vehicle inlet is on the right side. The vehicle connector of Combo1 and Combo 2 is derived from the AC Type 1 and Type 2 connector, respectively and retains the earth pin and the two signal pins namely, the control pilot and the proximity pilot. In addition, two DC power pins are added for fast charging. On the vehicle inlet, the pin configuration in the upper part is the same as $\mathrm{AC}$ Type 1 and Type 2 connector for AC charging while bottom two pins are used for DC charging.

- Maximum Voltage and Current Ratings

In general, CCS charger can deliver up to 350 Amps at a voltage of between 200 to $1000 \mathrm{~V}$ giving a maximum power output of $350 \mathrm{~kW}$. It must be kept in mind that these values are continuously updated to cater to the voltages and power requirements of new electric cars [30].

2) Cademo

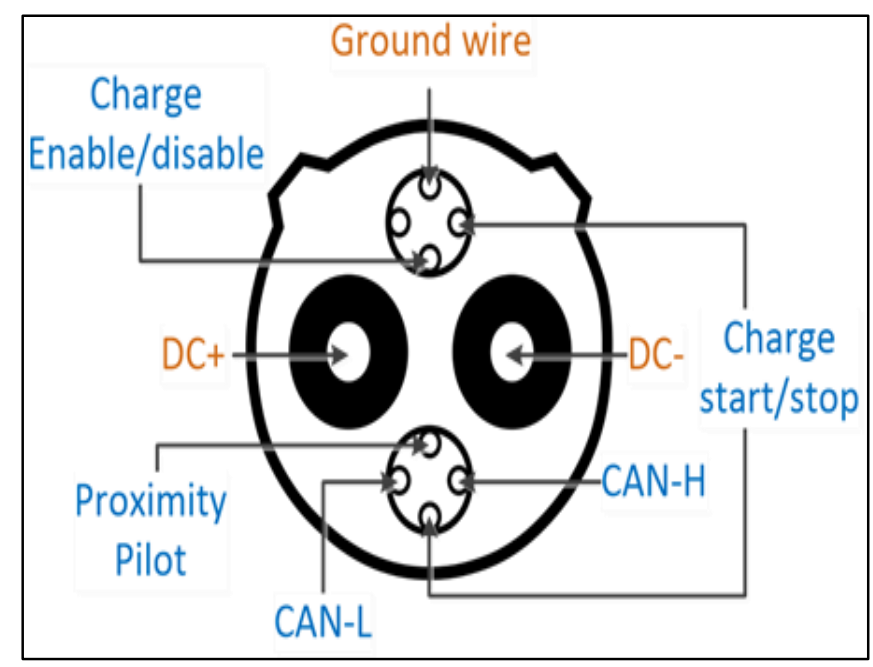

Fig 22:Cademo type DC connector

- Brief History and Usage Information

In March 2010, Toyota Motor Corporation, Nissan Motor Co. Ltd., Mitsubishi Motors Corporation, Fuji Heavy Industries Ltd., and Tokyo Electric Power Company, Inc. had formally established "CHAdeMO Association". In 2011, the first DC charger in Europe deployed. CHAdeMO has been published as IEC standard (IEC 61851-23, -24, as well as 62196-3) and IEEE standard (IEEE Standard 2030.1.1TM-2015). CHAdeMO is currently used as the DC charging part by all Japanese EV manufacturers. It has the largest global installation base of chargers as of 2017 with 16500 charging points. Further, CHAdeMO was the first DC standard to facilitate V2X via the 1.1 version of the protocol. - Pin Configuration

It is a Type $4 \mathrm{EV}$ connector and has 3 Power pins and 6 signal pins as shown in the figure. Chademo uses the Controller Area Network or CAN protocol in the communication pins for signalling.

- Maximum Voltage and Current Ratings

As of now, the voltage, current and power levels of chademo are $50-500 \mathrm{~V}$, up to $400 \mathrm{~A}$, thus providing a peak power of $200 \mathrm{~kW}$. In the future, it is expected that EV charging up to $1000 \mathrm{~V}$ and 400kW will be facilitated [31] [32] [33] [34].

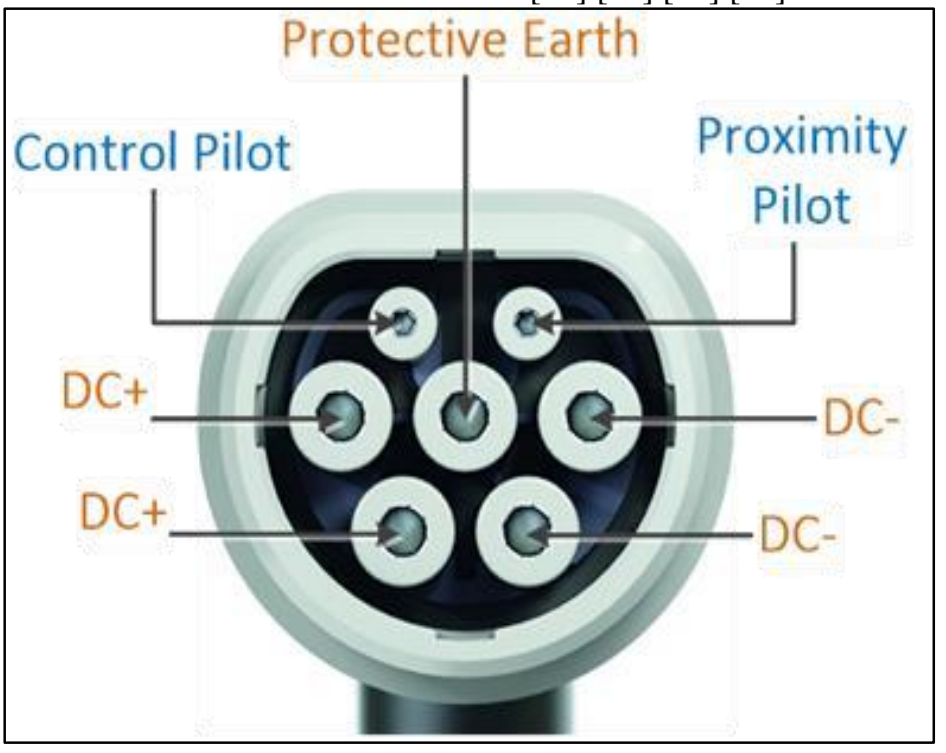

Fig. 23: DC charging Europe: Type 2 connector 
3) Tesla DC Chargers

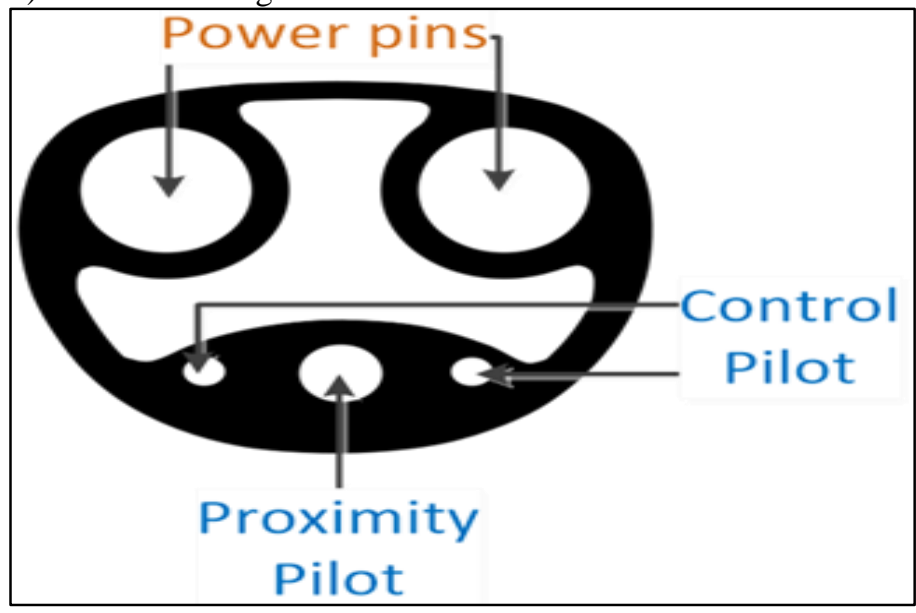

Fig. 24: DC charging in USA: Proprietary connector

- Brief History and Usage Information

Tesla superchargers in the US use their own proprietary charging connector, while the European variant uses the Type 2 connector, but with DC charging built in. The unique aspect of the Tesla connector is that same connector and pins are used for both AC and DC charging. Tesla offers an adapter than help the connector to be used with Chademo DC charging stations.

\section{- Pin Configuration}

The Tesla DC chargers like the AC chargers have two signal pins and three power pins - two pins for DC power and one for the earth.

- Maximum Voltage and Current Ratings

Tesla now offers DC charging up to $120 \mathrm{~kW}$ and this is expected to increase in the future.

\section{G. Limitations of Fast Charging}

Fast charging is quite attractive in the sense of high power charging with short charging times. But the fast charging power cannot be increased infinitely. That is due to five technical limitations.

1) Higher charging current leads to higher overall losses both in the charger and in the battery. As the charging currents increases, the effective capacity of the battery decreases as well (for example, as given by Peukert's law).

2) The battery $\mathrm{C}$-rate increases with fast charging and this reduces the battery lifetime due to the heat produced and increased degradation due to the higher temperature.

3) When fast charging a battery, the SOC of the battery can only be reached till $70-80 \%$. This is because fastcharging creates a lag between the voltage and state-ofcharge and this phenomenon increases as the battery is being charged faster. Hence, fast charging is typically done in the constant current or CC region of the battery charging and after that, the charging power is reduced in the constant voltage or $\mathrm{CV}$ charging.

4) For any EV charger, it is important that the cable is flexible and lightweight for people to use and connect it to the car. With higher charging power, thicker cables are needed to allow more charging current, else it will heat up due to the losses. In the future with currents above 250A, the charging cables would become heavy and less flexible to use. The solution would be to use thinner cables with cooling and thermal management to ensure that cables don't heat up. This is, of course, more complex and costly than using a cable without cooling. Table 6: EV Chargers \& Power Levels

\begin{tabular}{|c|c|c|}
\hline Plug & $\begin{array}{l}\text { Pin Configuration } \\
\text { (Communication) }\end{array}$ & $\begin{array}{c}\text { Voltage, Current, } \\
\text { Power }\end{array}$ \\
\hline $\begin{array}{l}\text { Type } 1 \\
\text { (SAE } \\
\text { J1772) }\end{array}$ & 3 power pins - L,N,E & $\begin{array}{c}1 \Phi 120 \mathrm{~V}, \leq 16 \mathrm{~A}, \\
1.9 \mathrm{~kW} \\
1 \Phi 240 \mathrm{~V}, \leq 80 \mathrm{~A}, \\
19.2 \mathrm{~kW}\end{array}$ \\
\hline Type 2 & $\begin{array}{c}4 \text { power pins }- \\
L 1, L 2, L 3, N, E \\
2 \text { control pins }-C P, P P \\
(P W M \text { over } C P) \\
\end{array}$ & $\begin{array}{c}1 \Phi 230 \mathrm{~V}, \leq \\
32 \mathrm{~A}, 7.4 \mathrm{~kW} \\
3 \Phi 400 \mathrm{~V} \\
63 \mathrm{~A}, 43 \mathrm{~kW} \\
\end{array}$ \\
\hline Chademo & $\begin{array}{c}3 \text { power }-D C+, D C-, E \\
7 \text { control pins }(C A N \\
\text { communication) }\end{array}$ & $\begin{array}{c}200-500 \mathrm{~V}, \leq 400 \mathrm{~A}, \\
200 \mathrm{~kW}\end{array}$ \\
\hline $\begin{array}{l}\text { CCS/ } \\
\text { Combo }\end{array}$ & $\begin{array}{l}3 \text { power pins }-D C+, D C \text { - } \\
\qquad E \\
2 \text { control pins }-C P, P P \\
(P L C \text { over } C P, P E)\end{array}$ & $\begin{array}{l}200-1000 \mathrm{VDC}, \leq \\
350 \mathrm{~A}, 350 \mathrm{~kW}\end{array}$ \\
\hline Tesla US & $\begin{array}{c}3 \text { power pins }- \\
D C+, D C-, E(\text { or }) L 1, N, E \\
2 \text { control pins }-C P, P P\end{array}$ & $\begin{array}{l}\text { Model } S, 400 \mathrm{~V}, \leq \\
300 \mathrm{~A}, 120 \mathrm{~kW}\end{array}$ \\
\hline
\end{tabular}

- USA and Japan have Type 1 AC, Type 4 Chademo DC, Combo $1 \mathrm{AC}-\mathrm{DC}$ and Tesla's proprietary AC connector.

- Europe has Type 2 AC, Type 3 AC, Type 4 Chademo DC and Combo 2 AC-DC China has Type 2 based AC and its own DC GB/T connector.

- With respect to car manufacturers, American, European, Korean car manufacturers have adopted CCS/Combo and Japanese car manufacturers have adopted Chademo.

- We have to bear in mind that as EVs are becoming popular across the globe, different countries are coming with their own choice of EV connectors or adopting one of the above connector's types. Further, the power levels are indicated in the tables are being updated by standardisation organization. Hence, this list is indicative and will get changed with time.

\section{H. List of EV Charging Standards}

IEC 62196-1/IEC 62196-2/IEC 62196-3: Plugs, socket outlets, Vehicle Connectors, Vehicle-Inlets - conductive charging of electric vehicles

Part 1: General requirements

Part 2: Dimensional compatibility and interchangeability requirements for $\mathrm{AC}$ pin and contact-tube accessories

Part 3: Dimensional interchangeability requirements for DC and $\mathrm{AC} / \mathrm{DC}$ pin and contact-tube vehicle couplers

IEC61851-1/-21/-22/-23/-24: Electric vehicle conductive charging system

Part 1: General requirements

Part 21-1: Electric vehicle on-board charger EMC requirements for conductive connection to an AC/DC

Part 21-2: EMC requirements for OFF board electric vehicle charging systems (under preparation) supply

Part 22: AC electric vehicle charging station (in future merged with 61851-1) 
Part 23: DC Electric vehicle charging station

Part 24: Control communication protocol between off-board DC charger and electric vehicle

ISO/IEC 15118-1/-2/-3: ISO/IEC

15118 - Road vehicles - Vehicle to

grid communication interface Part

1: General information and use-case

definition

Part 2 Technical protocol description and Open Systems

Interconnections (OSI) layer requirements

Part 3: Physical layer and Data Link layer requirements

Chinese GB/T

20234.1/.2/.3:

Connection set of

conductive charging for

electric vehicles Part 1:

General requirements

Part 2: AC charging coupler

Part 3: DC charging coupler

\section{Smart Charging}

Smart charging is a series of intelligent functionalities to control the EV charging power in order to create a flexible, sustainable, low cost and efficient charging environment. Benefits of Smart Charging

- It can increase the flexibility of charging by controlling the charging power, charging time duration and charging power flow direction.

- With the high charging flexibility, the utilization rates of fixed assets like transformers and power lines can be higher, which also helps in reducing the cost of EV charging.

- Smart charging can increase the efficiency of power transfer and help reduce the peak demand on the distribution network.

- EVs can be made more sustainable by charging them based on solar and wind generation. Moreover, smart charging can provide new revenue streams to $\mathrm{EV}$ owners like providing frequency regulation and vehicleto-grid services.

\section{1) $V 2 X$}

The battery power can flow from the vehicle to a home, to a building, to a load, etc. and it is called V2H, V2B, V2L, respectively. V2x is the generic term that is used to include all such applications [35] [36]. a) Key benefits of V2X technology

- It enables the storage of electricity in the car, especially from renewable sources which lead to emission reductions.

- By using the stored energy, the peak demand in the electrical grid can be reduced.

- Electric cars can now serve as an essential system component in an emergency power supply system.

- Ancillary services can be offered to the grid using an electric car with $\mathrm{V} 2 \mathrm{X}$ configuration providing a revenue stream to the EV user.

b) Main challenges for V2X

- V2x needs bidirectional chargers, which are bigger and costlier than unidirectional chargers.
- The lifetime of the battery inside the EV is partially reduced, since the bi-directional charging demands more charging cycles, causing additional degradation.

- Electric cars can now serve as an essential system component in an emergency power supply system.

- The ICT infrastructure, the required standardization and regulatory framework and financial incentives which are essential for the implementation of V2x are still under development.

Finally, it is important to note that vehicle-to-grid is currently not possible using $\mathrm{AC}$ chargers due to the technological limitations. This is because a bidirectional on-board charger is needed for vehicle-to-grid, but most current EVs only have a unidirectional charger. Further, V2x requires higher levels of communication between the EV and charger and this is not fulfilled by the simple PWM communication in Type 1 and Type 2 AC chargers. Hence, bidirectional off-board DC chargers are used for vehicle-to-grid applications using higher level of communication between the EV and charger using PLC, power line communication or CAN, control area network communication.

c) Application of smart charging

- Local load balancing

1) Adjust charging time/power according to load

2) Balance multiple charge points with priority

- Renewable energy utilization

- Price based charging

- Peak shaving

- $\quad$ Grid back up

\section{2) Local Load Balancing}

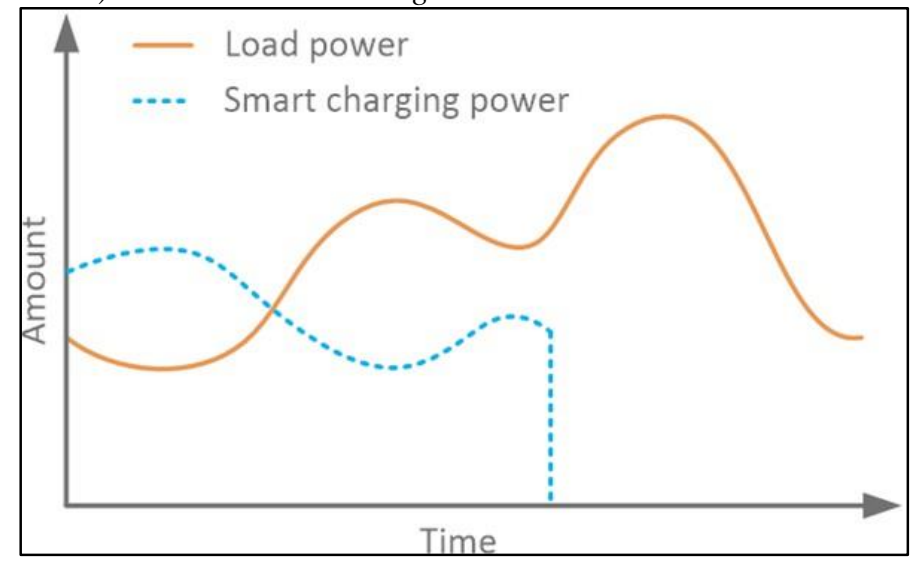

Fig. 25:Local Load Balancing

The first load balancing approach is to shift the charging time slot and to adjust the charging power based on the grid capacity and local loading condition. For example, when the load on the grid is low, the EV charging power can be increased. Alternately, if the load power increases, then the EV charging power can be subsequently reduced. Finally, the EV charging can be stopped if the grid is overloaded and remain so until the load power is back to normal.

The second approach is to balance multiple charge points with priority. With a limited maximum power for charging 
cars, smart charging can sequentially operate multiple charge points with priority, or adjust the power of each charging point so as to be within the maximum limit.

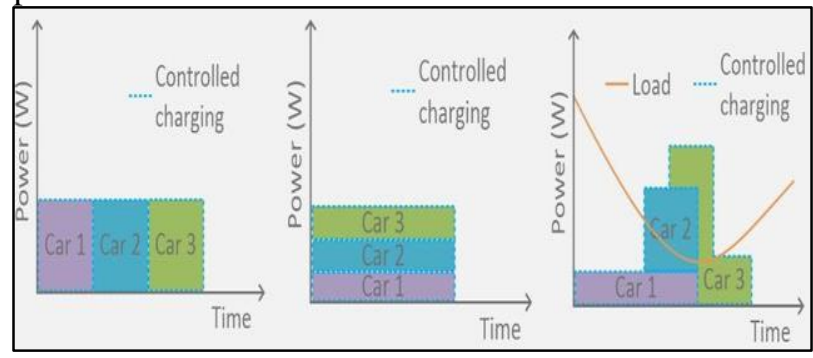

Fi2 Balancing Multiple Charging points

\section{3) Renewable Energy Utilization}

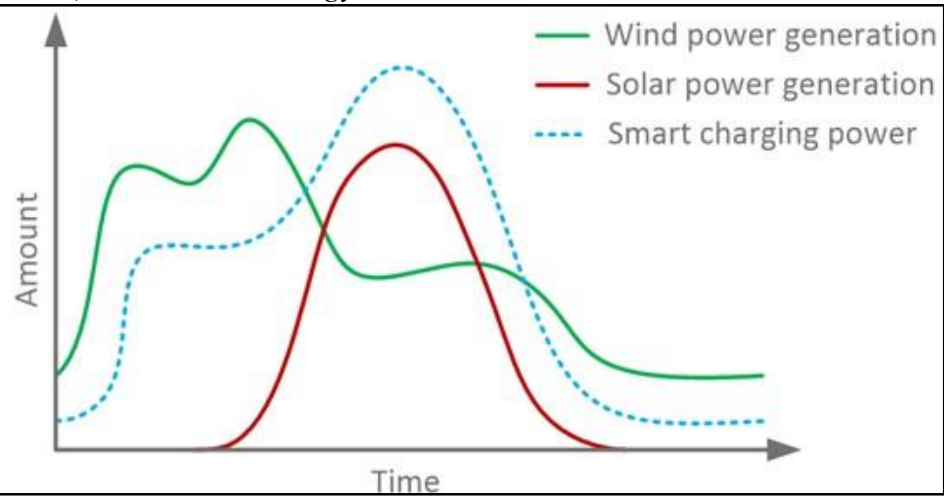

Fig. 27: Smart charging based on renewable energy production

Smart charging can help in controlling the charging power of the car based on the renewable energy production, say from solar and wind generators. Further, with V2G, the electric cars can be used as massive energy storage to balance the variable generation from renewable energy sources.

\section{4) Price Based Charging}

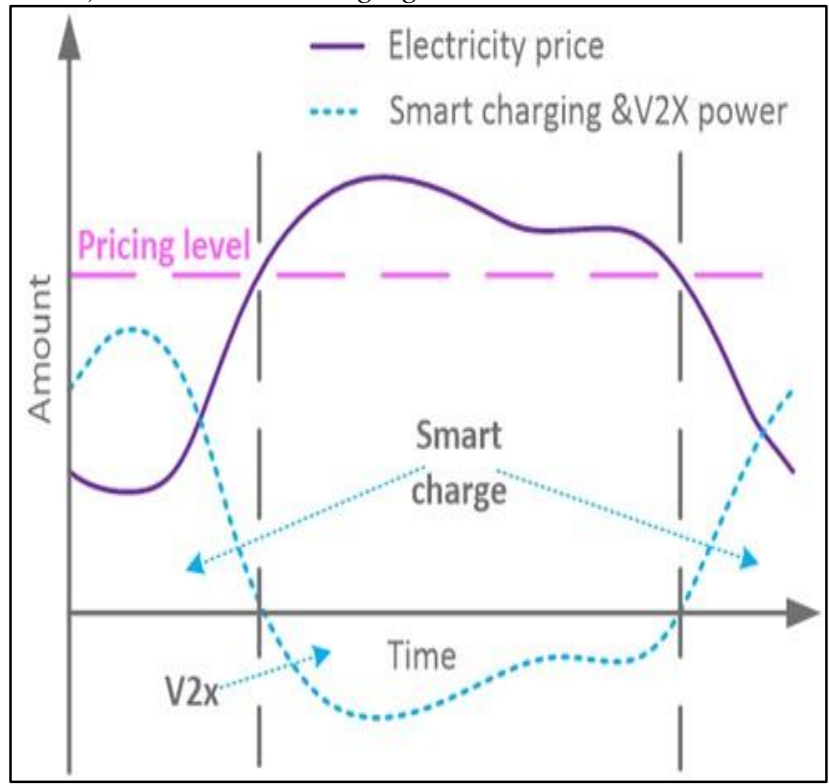

Fig28:Smart charging based on price of electricity

The charging power is increased when the electricity price is low, and the charging power is decreased or even stopped when the electricity price is high. Further, customers can get more profit when the V2x is applied. For example, we can charge the cars when the electricity is cheap and discharge the car via V2x when electricity is expensive and above a certain pricing level. In this case, the " $\mathrm{x}$ " of the "V2x" can be home, building or the grid.

\section{5) Peak Shaving}

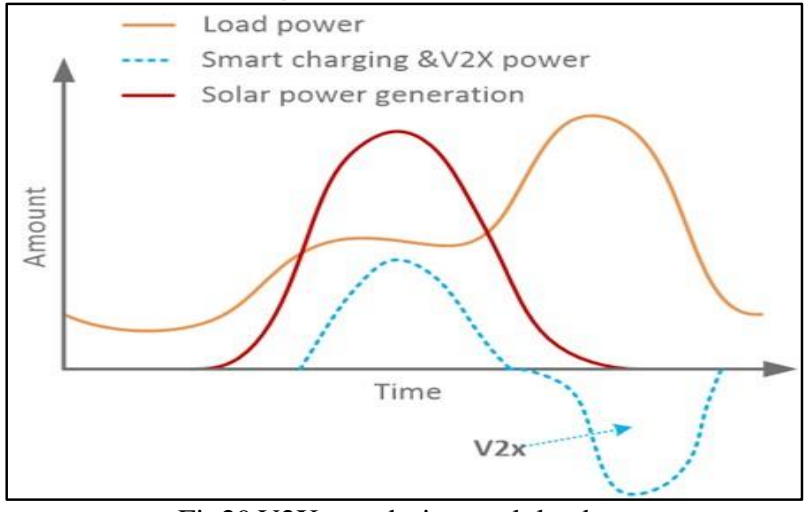

Fig29 V2X v during neak load

Here, the aggregated EVs can work as mass storage in the grid. With controlled charging, the EVs can be charged when there is extra renewable energy generation, and they can discharge via V2G to feed the grid when is a peak load in the evening. By doing so, the peak of both generation and consumption can be shifted, and the electric power demandsupply gap can be perfectly matched [37] [38].

\section{6) Grid Back Up}

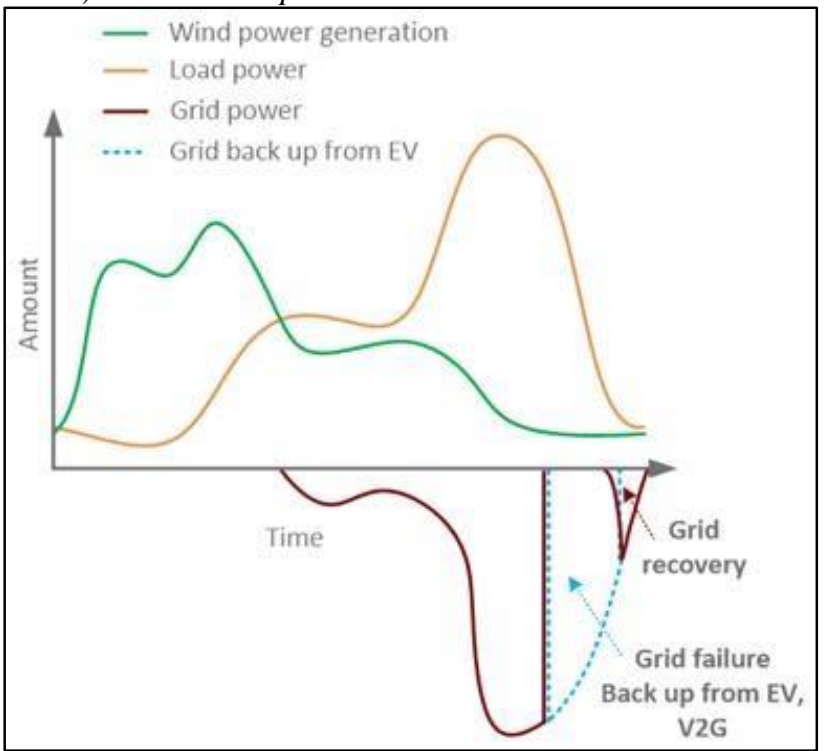

Fig.30:Backup power from EVs in condition of grid failure

Future battery developments [39] may change the economic equation, making it advantageous to use newer high capacity and longer-lived batteries in electric cars/plug-in hybrids (BEV/PHEVs). These newer batteries can be used in grid load balancing and as a large energy cache for renewable grid resources. Since BEVs can have up to $50 \mathrm{kWh}$ worth of battery storage they represent somewhat more than the average home's daily energy demand. Even without a PHEV's gas generation capabilities such a vehicle could be used for emergency power for several days (for example, lighting, home appliances, etc. with combined load of $1 \mathrm{~kW}$ could be powered for 50 hours). This would be an example 
of Vehicle-to-home transmission ( $\mathrm{V} 2 \mathrm{H})$. As such they may be seen as a complementary technology for intermittent renewable power resources such as wind or solar electric. Hydrogen FCEVs with tanks containing up to $5.6 \mathrm{~kg}$ of hydrogen can deliver more than $90 \mathrm{kWh}$ of electricity [40].

\section{REFERENCES}

[1] "Mitsubishi i-MiEV lineup expands for 2012 with cheaper "M" and extended-range "G"". green.autoblog.com. Retrieved 2014-02-01.

[2] "Vehicles - Department of Energy: Energy.gov". energy.gov. Retrieved 2014-05-03.

[3] "Car Traction Batteries - the New Gold Rush 2010-2020: IDTechEx". idtechex.com. Retrieved 2014-02-01.

[4] "Electric Vehicles in the United States: A New Model with Forecasts to 2030" (PDF). Archived from the original (PDF) on 2011-09-15. The 2012 per-mile cost under this scenario will be $10 \notin$ per mile. If the batteries are able to achieve 3,000 100-mile charge cycles and the vehicle is driven 15,000 miles per year, the 2012 per-mile cost is approximately $6.7 \not$ per mile. The likely lifetime of electric vehicle batteries is likely to fall somewhere within this range. The cost of electricity for electric cars is on the order of $2 \phi$ per mile, though electricity prices vary by region across the U.S.

[5] "Rapidly falling costs of battery packs for electric vehicles" by Björn Nykvist and Mans Nilsson, Nature Climate Change, March 2015.

[6] [Van den Bossche, P., et al., SUBAT: An assessment of sustainable battery technology. Journal of Power Sources, 2005. 162(2)]

[7] [Westbrook, M.H., The Electric Car: Development and future of battery, hybrid and fuel-cell cars. IEE Power Series no. 38. 2001] [8] [Automotive Handbook. 2000: Robert Bosch GmbH]

[9] [Westbrook, M.H., The Electric Car: Development and future of battery, hybrid and fuel-cell cars. IEE Power Series no. 38. 2001]

[10] [Van den Bossche, P., et al., SUBAT: An assessment of sustainable battery technology. Journal of Power Sources, 2005. 162(2)]

[11] [Resmini, F. and J. Ohlson, ZEBRA battery integration in "Think City" pure battery electric vehicle, in EVS24. 2009: Stavanger, Norway]

[12] [Adapted from Pistoia, G., Battery Operated Devices and Systems, 2009 Elsevier]

[13] [Kiehne, H.A., Battery Technology Handbook. 2nd ed. 2003: Marcel Dekker Inc]

[14] [Westbrook, M.H., The Electric Car: Development and future of battery, hybrid and fuel-cell cars. IEE Power Series no. 38. 2001]

[15] [Guidi, G., T.M. Undeland, and Y. Hori, Effectiveness of Supercapacitors as Power-Assist in Pure EV Using a Sodium-Nickel Chloride Battery as Main Energy Storage, in EVS24. 2009: Stavanger, Norway]

[16] [Troltzsch, U., et al., Characterizing Aging Effects of Lithium-Ion Batteries by Impedance Spectroscopy, Electrochimica Acta 51, 1667 1672, 2006] [17] [Linden, D. and T.B. Reddy, Handbook of Batteries. 3rd ed. 2001: McGraw Hill]

[35] [Pop, V., et al., Battery Management Systems: Accurate State-ofCharge Indication for Battery-Powered Applications. 2008: Springer Science and Business Media]
[18] Anderson, C.D. and Anderson, J. (2005) "New Charging Systems" Electric and Hybrid Cars: a History (North Carolina: McFarland \& Co., Inc.) ISBN 07864-1872-9, p. 121.

[19] "Toshiba's New Rechargeable Lithium-Ion Battery Recharges in Only One Minute" (Press release). Toshiba Corporation. 2005-03-29. Retrieved 2016-1214.

[20] "Neue Stromtankstelle: Elektroautos laden in 20 Minuten". golem.de (in German). 2011-09-15.

[21] Die Ladezeit dauert je nach Station zwischen 30 Minuten (Gleichstrom-Ladestation) und etwa acht Stunden (Haushaltssteckdose), zeit.de

[22] Die Akkus im Renault Zoe können in der schnellsten von vier Ladegeschwindigkeiten in 30 Minuten bis zu 80 Prozent aufgeladen werden, bild.de [24] Mit einem Schnellladegerät lässt sich der Akku des i3 in nur 30 Minuten zu 80 Prozent aufladen, golem.de

[25] "Forscher: Aluminium-Speicher "hat alles, was man sich für eine Batterie erträumen kann"" [Researcher: Aluminum storage "has everything you can dream for a battery"]. ecomento.tv (in German). German. 2015-04-13. Retrieved 2017-02-11.

[26] Lin, Meng-Chang; Gong, Ming; Lu, Bingan; Wu, Yingpeng; Wang, Di-Yan; Guan, Mingyun; Angell, Michael; Chen, Changxin; Yang, Jiang; Hwang, BingJoe; Dai, Hongjie (2015-04-06). "An ultrafast rechargeable aluminium-ion battery". Nature. US. 520: 324-328. doi:10.1038/nature14340. Retrieved 201702-11.

[27] "Elektroauto mit 1088 PS entwickelt" (in German). 2014-10-24. Retrieved 2015-04-12.

[28] "40( $\min ) / 15(\min 80 \%) "$. byd-auto.net. Archived from the original on 2016-02-06. [29] http://www.charinev.org/members/.

[30] https://www.charinev.org

[36] List of Chademo compatible EVs: https://www.chademo.com/products/evs/ List of Chademo charger

[37] Manufacturers: https://www.chademo.com/products/chargers/

[38] List of Chademo V2X chargers: https://www.chademo.com/products/v2X-product/

[31] [34] www.chademo.com.

[39] Sortomme, Eric, and Mohamed El-Sharkawi. "Optimal charging strategies for unidirectional vehicle-to-grid." Smart Grid, IEEE Transactions on 2.1 (2011): 131-138.

[40] Yong, Jia Ying, et al. "A review on the state-of-the-art technologies of electric vehicle, its impacts and prospects." Renewable and Sustainable Energy Reviews 49 (2015): 365-385.

[41] Woody, Todd (2007-06-12). "PG\&E's Battery Power Plans Could Jump Start Electric Car Market". Green Wombat. Archived from the original on 2007-0814. Retrieved 2007-08-19.

[42] US 4317049, SCHWEPPE, FRED C., "Frequency adaptive, powerenergy re-scheduler", published 1982-02-23

[43] "Toshiba's New Rechargeable Lithium-Ion Battery Recharges in Only One Minute" (Press release). Japan: Toshiba Corporation. 2005-03-29. Retrieved 200712-05.

[44] Wassink, Jos (2016-07-18). "Hydrogen car as power backup". Delta TU Delft. Retrieved 2017-11-07. 